\title{
Forty years of study on interactions between walnut tree and arbuscular mycorrhizal fungi. A review
}

\author{
Emma Mortier ${ }^{1} \cdot$ Olivier Lamotte $^{1} \cdot$ Fabrice Martin-Laurent $^{1} \cdot$ Ghislaine Recorbet $^{1}$
}

Accepted: 12 October 2020 / Published online: 2 November 2020

(C) The Author(s) 2020

\begin{abstract}
Walnut trees are among the most important hardwood species in the northern hemisphere, ecologically and economically. They are mainly cultivated for timber and nut production but are also attractive ornamental trees in parks. Establishing walnut orchards is difficult because seedlings have a coarse root architecture and few of them survive to transplanting. Planting success is mainly determined by the root system morphology and the nutrient status of the seedlings, so that rhizosphere conditions are critical for plant performance. Walnut trees can associate with soil-borne arbuscular mycorrhizal fungi, which are obligate biotrophs. In this association, plant-produced carbon compounds are traded against fungus-acquired soil mineral nutrients. The beneficial effect of arbuscular mycorrhizal symbiosis on hardwood seedling quality and field performance has long been known, but an integrated view is lacking about the effects of arbuscular mycorrhizas on walnut cropping. Therefore, we surveyed the literature published over the last 40 years to provide up-to-date knowledge on the relationships between arbuscular mycorrhizas and walnut trees. Our review outlines the major following points: (1) the arbuscular-mycorrhiza-mediated nutrient uptake capacity of walnut trees is associated with first- to third-order roots, and fibrous tip-ended roots are dependent on arbuscular mycorrhizal fungi, whereas pioneer roots are not; (2) early inoculation with arbuscular mycorrhizal fungi improves the survival and seedling performance attributes of transplanted walnut trees: biotization enhances walnut transplant success by increasing the number of lateral roots and plant P uptake, but these benefits are fungus- and host-dependent; (3) in the context of walnut agroforestry, deeply rooted walnut trees play a role as reservoirs of arbuscular mycorrhizal fungal propagules for the surrounding vegetation, but tree shade and soluble phosphate availability decrease walnut mycorrhizal dependency; and (4) the arbuscular mycorrhizal mycelium mediates the transport of juglone and thus plays a role in walnut tree allelopathy.
\end{abstract}

Keywords Juglans $\cdot$ Symbiosis $\cdot$ Rootstock $\cdot$ Acclimatization $\cdot$ Fertilization $\cdot$ Agroforestry $\cdot$ Juglone $\cdot$ Common mycelial networks

\section{Contents}

1. Introduction

2. Arbuscular mycorrhizal colonization of walnut trees is related to root architecture and anatomy

2.1 Root diameter and branching order of absorptive roots 2.2 Fibrous vs. pioneer roots

3. Impact of arbuscular mycorrhizal biotization on walnut survival and seedling quality attributes

Ghislaine Recorbet

ghislaine.recorbet@inrae.fr

1 AgroSup Dijon, CNRS, INRAE, University of Bourgogne, Univ. Bourgogne Franche-Comté, Agroécologie 17 rue de Sully, BP 86510, 21065 Dijon, France
3.1 Survival of walnut seedlings after ex vitro acclimatization and field transplanting

3.2 Walnut seedling quality attributes

3.3 Benefits are fungus- and host-dependent

4. Arbuscular mycorrhizal fungi in walnut agroforestry systems

4.1 Arbuscular mycorrhizal inoculum density and diversity in walnut agroforestry systems

4.2 Arbuscular mycorrhizal dependency in walnut agroforestry systems

4.3 Arbuscular mycorrhizal fungal and interference competition in walnut agroforestry systems

5. Conclusion

Acknowledgements

References 


\section{Introduction}

Walnut is the common name given to twenty-one to twentyfive species of deciduous trees belonging to the genus Juglans (order Fagales, family Juglandaceae), characterized by a monoecious and dichogamous habit (Manning 1978; Gleeson 1982; Germain 1992; Willis 2000; Shah et al. 2018; Bernard et al. 2018). Juglans trees have been classified into four sections according to leaf, flower, and fruit morphology (Table 1), namely, Trachycaryon (one species: J. cinerea), Rhysocaryon (black walnuts), Cardiocaryon (heartnuts), and Dioscaryon (one species: J. regia) (Manning 1978; Bernard et al. 2018). The genus is mostly distributed across the temperate and subtropical regions of the northern hemisphere, and several species are also found in Central America and along the Andes Mountains in western South America (Bailey and Bailey 1976; Bernard et al. 2018). By providing wood, ornamental, and nutrition value to human beings, and food and a habitat to wildlife, walnuts are among the most important trees in the northern hemisphere, ecologically and economically (Bernard et al. 2018). The fruit is renowned as a rich source of unsaturated fatty acids, proteins, vitamins $\mathrm{E}$ and B1, selenium, and iron (Bender and Bender 2005). It also contains a wide variety of flavonoids, phenolic acids, and related polyphenols, which have antioxidant and anti-inflammatory properties (Martinez et al. 2010; Delaviz et al. 2017; Jaiswal and Tailang 2017). Bark or leaf extracts are notably used worldwide in traditional medicine (Amaral et al. 2004). Besides nuts and leaves, walnut is grown for its high-quality wood that is marketable for many uses, including furniture, gunstocks, veneers, and paneling (Payghamzadeh and Kazemitabar 2011). In addition to direct economic benefits, various ecosystem services among which complementarities in resource-capture strategies and enhanced soil fertility have been reported from hardwood-based agroforestry systems (Jose 2009; Bainard et al. 2011; Shukla et al. 2012).

As listed in Table 1, among the major species grown for commercial use are the Persian or English walnut (J. regia L.), the eastern black walnut ( $J$. nigra L.), the northern California black walnut ( $J$. hindsii Jeps.), and white walnut ( $J$. cinerea L.). All species produce nuts, but $J$. regia is the main species widely cultivated for nut production, with worldwide in-shell walnut production exceeding $3400 \mathrm{kt}$ per year (www.nutfruit. org 2014; Bernard et al. 2018). The eastern black walnut ( $J$. nigra L.) is also grown for its edible nuts, but is valued economically for its high-quality wood. The nut of the black walnut is of high flavor, but due to its hard shell and poor hulling characteristics, it is not grown for commercial production (Verma 2014). Other walnut species used for valuable timber production include $J$. regia, J. cinerea, J. major, J. neotropica, J. olanchana, and J. mandshurica (Table 1). The primary commercial importance of the Northern California black walnut ( $J$. hindsii) is as a rootstock for commercial Persian walnut (J. regia) orchards or as a parent of the widely used hybrid rootstock "Paradox" ( $J$. hindsii x $J$. regia) (Verma 2014). Walnuts are now distributed across 60

Table 1 Main walnut species grown for commercial use according to Manning (1978), Bernard et al. (2018), and Shah et al. (2018)

\begin{tabular}{|c|c|c|c|}
\hline Section & Species (vernacular name) & Geographic distribution & Commercial use \\
\hline Dioscaryon (Common walnut) & J. regia L. (Persian or English walnut) & $\begin{array}{l}\text { SE Europe, Iran to the } \\
\text { Himalayas, China }\end{array}$ & Nuts-High-quality timber \\
\hline \multirow[t]{6}{*}{ Rhysocarion (Black walnut) } & J. nigra L. (Eastern black walnut) & Eastern United States & $\begin{array}{l}\text { Timber-ornamental } \\
\text { tree-rootstock-cosmetics-abrasive and } \\
\text { filtering properties }\end{array}$ \\
\hline & $\begin{array}{l}\text { J. hindsii Jeps. (Northern California } \\
\text { black walnut) }\end{array}$ & Northern California & $\begin{array}{l}\text { Rootstock orchard of } J \text {. regia-ornamental } \\
\text { tree-timber }\end{array}$ \\
\hline & $\begin{array}{l}\text { J. microcarpa Berl. (Texas or little } \\
\text { black walnut) }\end{array}$ & $\begin{array}{l}\text { SW United States } \\
\text { NW Mexico }\end{array}$ & Interbreeding with $J$. major and $J$. nigra \\
\hline & J. major Heller (Arizona black walnut) & $\begin{array}{l}\text { SW United States } \\
\text { NW Mexico }\end{array}$ & Carpentry wood \\
\hline & $\begin{array}{l}\text { J. neotropica Diels (Andean, } \\
\text { Ecuadorian or Columbian walnut) }\end{array}$ & NW South America & Wood (floor and decoration) \\
\hline & $\begin{array}{l}\text { J. olanchana Standl. \& Williams } \\
\text { (Cedro Negro) }\end{array}$ & Guatemala & Wood (furniture and lute-making) \\
\hline Trachycarion (White walnut) & J. cinerea L. (Butternut) & Eastern United States & $\begin{array}{l}\text { Lumber industry (furniture) - Medicine (cathartic } \\
\text { properties) }\end{array}$ \\
\hline \multirow[t]{2}{*}{ Cardiocaryon (Heartnut) } & $\begin{array}{l}\text { J. mandshurica Maxim. (Manchurian } \\
\text { walnut) }\end{array}$ & $\begin{array}{l}\text { Manchuria, NE China, } \\
\text { Korea }\end{array}$ & Timber-ornamental tree \\
\hline & J. ailantifolia Carr. (Japanese walnut) & Japan & Dye \\
\hline
\end{tabular}

Abbreviations: $S E$ southeastern, $S W$ southwestern, $N E$ northeastern, $N W$ northwestern 
countries around the globe as both commercial and ornamental trees (Avanzato et al. 2014).

Walnut cropping mainly relies on the propagation of cultivars of biological and economic interest. To ensure topquality orchard trees, walnuts are mainly managed and grown to a suitable size in nurseries after grafting onto seedling rootstocks selected to provide the best anchorage, vigor, and resistance or tolerance to soil-borne pests and diseases (Lopez 2004; Verma 2014). However, poor survival after planting and slow growth rates are common difficulties encountered when establishing Juglans orchards (Jaynes 1979; Peixe et al. 2015). Studies on hardwood species indicate that the root system morphology is one of the major determinants of seedling field performance because it provides anchorage into the soil matrix and favors nutrient uptake (Kormanik 1986; Kormanik 1989; Schultz and Thompson 1990; Grossnickle and MacDonald 2018). The nutritional status of nursery seedlings has a direct effect on factors related to their survival after planting. Storage of mineral nutrients such as nitrogen $(\mathrm{N})$, phosphorus $(\mathrm{P})$, and potassium $(\mathrm{K})$ by seedlings has a particularly positive impact on their survival and development after planting (Landis 1985; Landis et al. 1989). In this context, the rhizosphere, namely, the region of the soil in intimate interaction with the roots, is critical for plant performance as it contains a complex array of plant-associated communities of organisms vital for soil and plant health (Bowen and Rovira 1999; Buée et al. 2009). As such, ecosystem functions can be improved by managing the rhizosphere microbiome (Bender et al. 2016).

The roots of most tree species are notably colonized by specialized soil-borne fungi that form symbiotic associations called mycorrhizas (Brundrett 1991, 2009; Kariman et al.
2018). Mycorrhizal fungi play a key role in assisting plants in the acquisition of mineral nutrients, especially $\mathrm{N}, \mathrm{P}$, and $\mathrm{K}$ (Smith and Read 2008; Koide et al. 2014; Garcia and Zimmermann 2014). Mycorrhizal fungi also confer protection against pathogens and root herbivores (Arya et al. 2010) and mediate carbon (C) transfer among plants (Simard et al. 1997; Lerat et al. 2002; Teste et al. 2009). Juglans hardwood species associate almost exclusively with arbuscular mycorrhizal (AM) fungi (Brundrett 1991, 2002; Comas and Eissenstat 2009; Comas et al. 2014), which belong to an ancient lineage of obligate biotrophs in the sub-phylum Glomeromycotina (Spatafora et al. 2016). AM fungi colonize plant roots to obtain plant-derived carbon in the form of sugars and lipids to sustain their growth and reproduction (Keymer et al., 2017). In return, AM fungi provide soil mineral nutrients to the host, which are acquired through the fungal extra-radical mycelium (ERM) that reaches soil volumes inaccessible to plant roots (Friese and Allen, 1991; Gutjahr and Parniske 2013; Rich et al. 2017; Roth and Paszkowski 2017; Wang et al. 2017). Fine (1$5 \mu \mathrm{m}$ ) fungal hyphae (Bago et al. 1998) give plants access to soil inorganic phosphate $(\mathrm{Pi})$ and inorganic $\mathrm{N}$ in the form of nitrates $\left(\mathrm{NO}_{3}{ }^{-}\right)$and ammonium $\left(\mathrm{NH}_{4}{ }^{+}\right)$(Harrison et al. 2002; Hodge and Fitter 2010; Bücking and Kafle 2015; Chen et al. 2018). During mycorrhizal nutrient uptake, soil $\mathrm{Pi}$ and $\mathrm{N}$ are acquired by high-affinity transporters located in the extraradical hyphae and translocated to fungal arbuscules (Fig. 1). These tree-shaped invaginations develop in root cortex cells and enable nutrient exchanges between the two partners (Gutjahr and Parniske 2013; Bücking and Kafle 2015).

AM fungi act as a major biotic component of the rhizosphere because they improve plant development and nutritional status, reduce planting stress, and increase the field
Fig. 1 Illustrations after Trypan blue staining of a AM fungal development in walnut roots with fungal hyphae (h), vesicles (v), and arbuscules (a), and $\mathbf{b}$ an arbuscule consisting of highlybranched fungal hyphae that develop in root cortex cells where nutrient exchanges occur between the host and the fungus

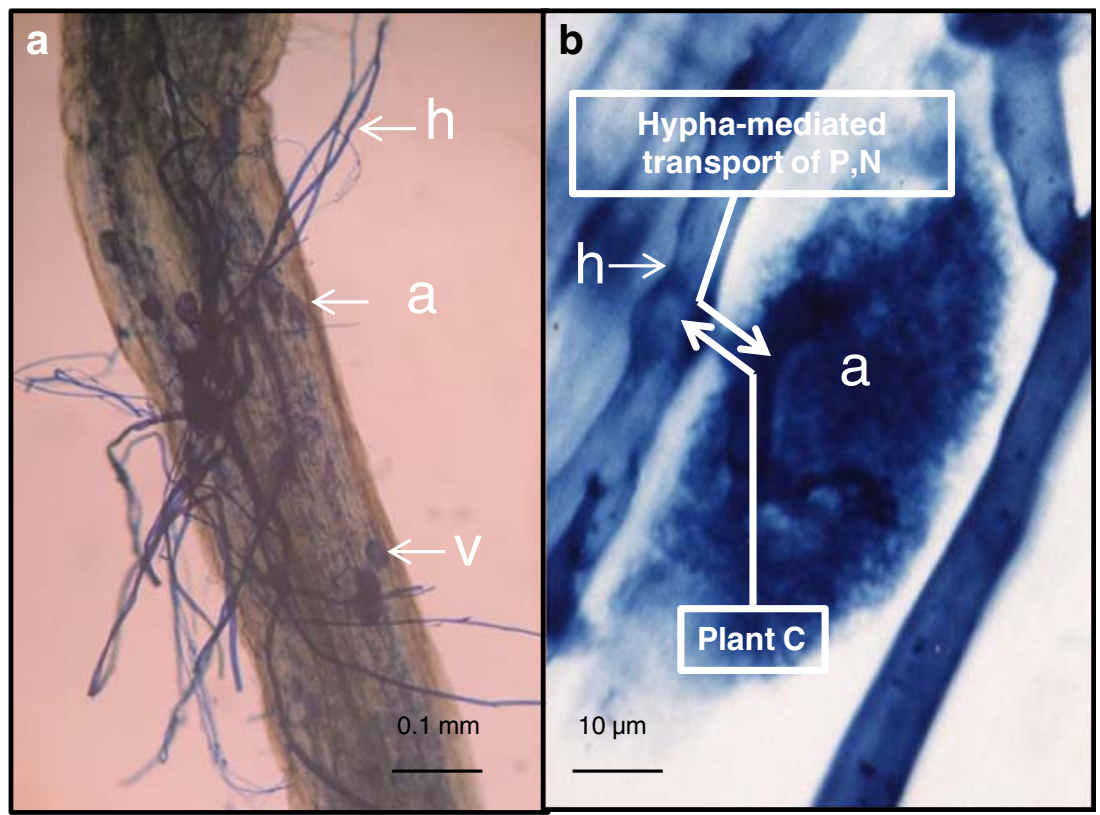


survival rate of seedlings (Carpio et al. 2003; Davies 2008). The role of AM symbiosis in improving hardwood seedling quality and field performance has long been known (Kormanik et al. 1982; Kormanik 1985; Cordell et al. 1987), but an integrated view of the agronomic role of arbuscular mycorrhizas in walnut cropping is still lacking. Based on a survey of the literature published over the last 40 years, the present manuscript aims at providing upto-date knowledge on arbuscular mycorrhiza-walnut tree relationships. As schematized in Fig. 2, this review describes the AM colonization process of walnut as related to root morphology and anatomy. It further addresses benefits from AM biotization, which are fungus- and host-dependent. Finally, it highlights positive and negative feedbacks between walnut planting and AM fungi. The conclusion proposes future lines of research to bridge current knowledge gaps.

\section{Arbuscular mycorrhizal colonization of walnut is related to root architecture and anatomy}

Trees usually form two main types of mycorrhizal associations: AM associations with fungi from the phylum
Mucoromycota (Bonfante and Venice 2020), and ectomycorrhizal (EM) associations with fungi mostly from the Ascomycota and Basidiomycota phyla (Wang and Qiu 2006; Brundrett 2009). Trees within a given genus usually have the same type of mycorrhiza, and these relationships are generally also consistent within families. Juglandaceae is an outlier family in which Carya spp. forms the EM type, whereas Juglans spp. predominantly displays the AM type (Brundrett 1991). The mycorrhizal association type is not systematically related to the phylogenetic relatedness of the host tree: trees associated with different mycorrhizal types profoundly differ in root traits related to nutrient foraging (Liese et al. 2017; Kong et al. 2019). Knowledge about the root architectural and morphological features associated with AM colonization is therefore required to understand walnut acquisition of belowground resources.

\subsection{Root diameter and branching order of absorptive roots}

Enhanced nutrient uptake is the major benefit for AM plants. Mycorrhizal dependency has thus been defined as the plant's inability to grow in the absence of mycorrhizas at a given soil fertility level (Gerdemann 1975; Siqueira and Saggin-Júnior

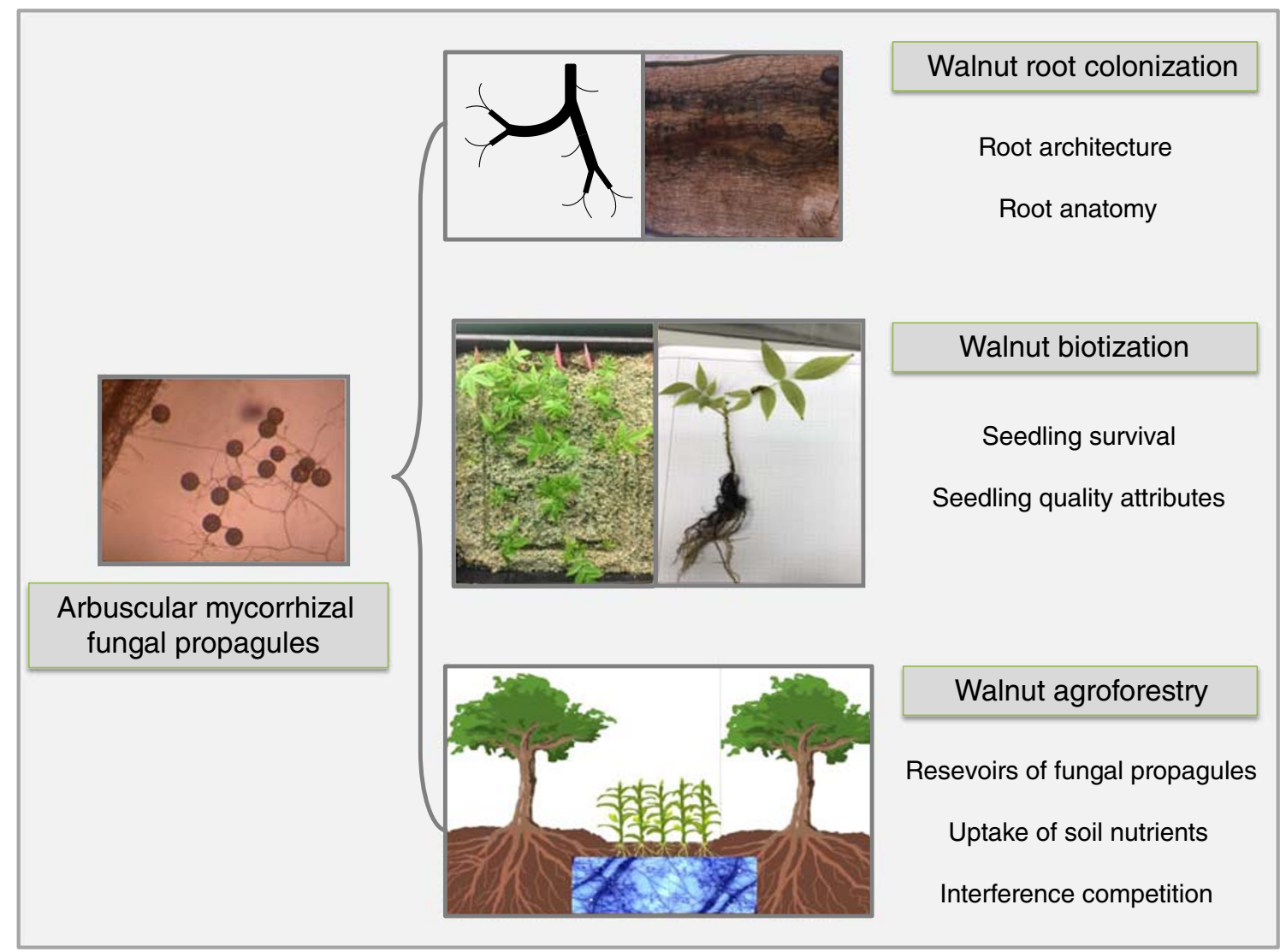

Fig. 2 Walnut tree roots interacting with arbuscular mycorrhizal fungi 
2001; Janos 2007). As such, mycorrhizal dependency is an intrinsic property of a plant species or genotype, and largely controlled by the root system architecture (Baylis 1975; Plenchette et al. 1983; Janos 2007). Traits of absorptive roots (roots less than 1 or $2 \mathrm{~mm}$ in diameter) are indicators of the nutrient and water uptake capacities (Pregitzer 2002; Pregitzer et al. 2002; Guo et al. 2008). Plant species with thin absorptive roots are efficient in nutrient foraging and do not invest in $\mathrm{AM}$ fungi in P-limited soils (Bates and Lynch 2001; Hodge 2004; Liu et al. 2015). On the contrary, thick-root species have a limited intrinsic ability to absorb nutrients (Bates and Lynch, 2001). They are thus assumed to benefit from the presence of finely structured AM fungal hyphae that increase the surface area available for absorbing nutrients, especially $\mathrm{P}$ (Raven and Edwards 2001; Comas et al. 2014; Eissenstat et al. 2015; Liu et al. 2019). Walnut absorptive roots have a coarse root architecture. Chen et al. (2016) reported contrasted root thicknesses for Juglans nigra (AM-type) and Carya glabra (EM-type), with mean root diameters of $0.36 \mathrm{~mm}$ and $0.19 \mathrm{~mm}$, respectively. Thicker Juglans spp. absorptive roots are thus able to support more arbuscular mycorrhizas per unit root length or mass because AM fungi form associations within cortical cells along the root axis (Brundrett 2002, 2009; Guo et al. 2008; Zadworny and Eissenstat 2011; Unger et al. 2017). In contrast, in EM associations, fungi predominantly form Hartig nets in the intercellular spaces of root tips, so that fine root systems are more adapted to EM fungal colonization (Brundrett 2002; Comas et al. 2014).
It has become increasingly clear in the last two decades that the terminal branched root system of perennial plants consists of individual units, with distinct traits (Guo et al. 2008; Salahuddin et al. 2018). Terminal root units consist of several orders that have been classified according to their branching position, with the thinnest, most distal ones termed 1 st-order roots, as schematized in Fig. 3a-b (Pregitzer et al. 2002). The analysis of 23 temperate tree species, including Juglans spp., clearlyshowed that different branching orders display marked differences in anatomy (Guo et al. 2008). Based on (1) the stele-to-root-diameter ratio, (2) mycorrhizal colonization, and (3) the presence of secondary xylem (SX) and a continuous cork layer (CCL), five branching orders have been separated into two groups. In the Chinese key timber species J. mandshurica (Table 2), the two or three distal orders have been linked to resource uptake, as inferred from the presence of mycorrhizal colonization, a low stele-to-root-diameter ratio, and no sign of secondary growth. Fourth- and higher-order roots have no mycorrhizal colonization and display a high stele-to-rootdiameter ratio, indicating a limiting nutrient uptake capacity (Guo et al. 2008). As illustrated for J. regia in Fig. 3c-d, these results show that AM colonization occurs in first- to third-order roots and is generally absent in the fourth and fifth orders. In summary, root anatomy and function change with position in a branching hierarchy and the AM nutrient uptake capacity of walnut trees are associated with first- to third-order roots.
Fig. 3 Illustrations of a root branch classification into orders numbered from 1 to 4 , according to their position, with the thinnest, most distal roots identified as the first order; $\mathbf{b}$ root branch order labeling of 2-month-old J. regia seedlings; Trypan blue-stained extra-radical hyphae (h) of Rhizophagus irregularis DAOM 197198 in the vicinity of $\mathbf{c}$ first-, or $\mathbf{d}$ second- and third-order roots of 2-month-old J. regia seedlings

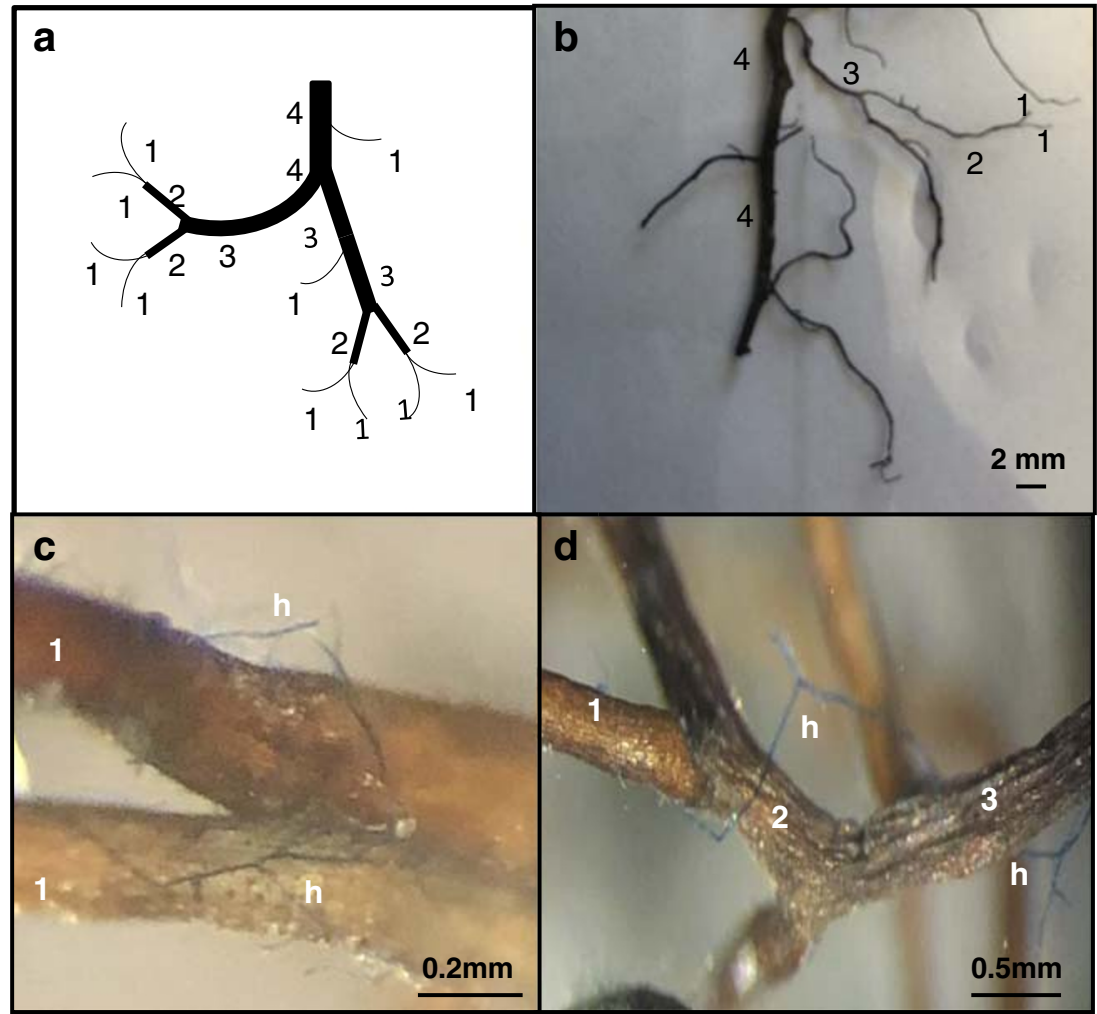


Table 2 Arbuscular mycorrhizal (AM) colonization of Juglans spp. as related to root traits according to [1] Guo et al. (2008) and [2] Zadworny and Eissenstat (2011)

\begin{tabular}{|c|c|c|c|c|c|c|c|}
\hline Juglans species & Parameter & & & & & & Ref. \\
\hline \multirow{5}{*}{$\begin{array}{l}J . \text { mandshurica } \\
\text { (50 years old })\end{array}$} & Root order & 1 & 2 & 3 & 4 & 5 & Guo et al. (2008) \\
\hline & AM colonization & Yes & Yes & Yes & No & No & Guo et al. (2008) \\
\hline & Presence rate of secondary xylem $(\%)$ & 0 & 0 & $<100$ & 100 & 100 & Guo et al. (2008) \\
\hline & $\begin{array}{l}\text { Presence rate of continuous cork layer } \\
(\%)\end{array}$ & 0 & 0 & 0 & 100 & 100 & Guo et al. (2008) \\
\hline & Mean stele-to-root-diameter ratio & $0.2 \mathrm{a}$ & $0.3 \mathrm{a}$ & $0.4 \mathrm{~b}$ & $\begin{array}{r}0.7 \\
\mathrm{c}\end{array}$ & $0.8 \mathrm{c}$ & Guo et al. (2008) \\
\hline \multirow[t]{4}{*}{ J. nigra $(<14$ days old $)$} & Root order & $\begin{array}{l}1 \text { Fibrous } \\
\text { roots }\end{array}$ & $\begin{array}{l}1 \text { Pioneer } \\
\text { roots }\end{array}$ & NA & NA & NA & $\begin{array}{l}\text { Zadworny and Eissenstat } \\
\text { (2011) }\end{array}$ \\
\hline & Mean number of hypodermal layers & $1.0 \mathrm{a}$ & $5.9 \mathrm{a}$ & & & & $\begin{array}{l}\text { Zadworny and Eissenstat } \\
\text { (2011) }\end{array}$ \\
\hline & Passage cells (\%) & $15 \mathrm{a}$ & $0 \mathrm{~b}$ & & & & $\begin{array}{l}\text { Zadworny and Eissenstat } \\
\text { (2011) }\end{array}$ \\
\hline & AM colonization $(\%)$ & $21 \mathrm{a}$ & $0 \mathrm{~b}$ & & & & $\begin{array}{l}\text { Zadworny and Eissenstat } \\
\text { (2011) }\end{array}$ \\
\hline \multirow[t]{4}{*}{ J. nigra (>2 years old $)$} & Root order & $\begin{array}{l}1 \text { Fibrous } \\
\text { roots }\end{array}$ & $\begin{array}{l}1 \text { Pioneer } \\
\text { roots }\end{array}$ & & & & $\begin{array}{l}\text { Zadworny and Eissenstat } \\
\text { (2011) }\end{array}$ \\
\hline & Mean number of hypodermal layers & $1.0 \mathrm{a}$ & $4.5 \mathrm{a}$ & & & & $\begin{array}{l}\text { Zadworny and Eissenstat } \\
\text { (2011) }\end{array}$ \\
\hline & Passage cells (\%) & $10 \mathrm{a}$ & $0 \mathrm{~b}$ & & & & $\begin{array}{l}\text { Zadworny and Eissenstat } \\
\text { (2011) }\end{array}$ \\
\hline & AM colonization $(\%)$ & $34.5 \mathrm{a}$ & $0 \mathrm{~b}$ & & & & $\begin{array}{l}\text { Zadworny and Eissenstat } \\
\text { (2011) }\end{array}$ \\
\hline
\end{tabular}

Letters that differ within a line indicate significant $(P<0.05)$ differences

NA not addressed

\subsection{Fibrous vs. pioneer roots}

Further work on AM tree species, including J. nigra, revealed that the roots emitted as first-order branches are not all the same (Zadworny and Eissenstat 2011). All fine roots start their life as first-order roots, but only a subset grows into higherorder roots (Pagès 2002). These pioneer roots explore the soil to expand the root system and have a relatively long mean lifetime because they undergo secondary growth (Wells and Eissenstat 2001; Zadworny and Eissenstat 2011). In contrast, fibrous roots are ephemeral, do not undergo secondary growth, and are primarily associated with nutrient absorption (Wells and Eissenstat 2001; Xia et al. 2010; Zadworny and Eissenstat 2011). In both young ( $<14$ day-old) and mixed-age $J$. nigra roots harvested after 2 years (Table 2), the hypodermis of fibrous roots was composed of only one layer of cells, while the hypodermis of pioneer roots was multi-layered (Table 2) (Zadworny and Eissenstat 2011). In addition, the relative frequency of passage cells (cells with no evidence of secondary wall thickening) was lower in pioneer roots than in fibrous roots (Table 2). Passage cells refer to hypodermal cells deprived of a suberin lamella; they are the only cells through which AM fungi gain access to the inner cortex (Smith and
Read 1997; Brundrett and Kendrick 1988). The abundance of passage cells per root explains almost all the variability in the number of AM fungi penetration points per root (Sharda and Koide 2008). Importantly, Zadworny and Eissenstat (2011) revealed a complete lack of AM colonization in pioneer roots when compared with fibrous roots. Mycorrhizal colonization therefore strictly differs between pioneer and fibrous roots, and fibrous roots are dependent on AM fungi for nutrient acquisition.

\section{Impact of arbuscular mycorrhizal biotization on walnut survival and seedling quality attributes}

Walnut saplings are produced by seed propagation or plant tissue culture. Whatever the method, survival in field conditions is low (Jacobs et al. 2005a; Hackett et al. 2010). For most mycotrophic hardwood species, including Juglans spp., the successful establishment of seedlings largely depends on AM association and on the ability to acquire resources rapidly after planting (Smith and Read 2008). This has led to considerable interest in evaluating the significance of inoculating 
walnut saplings (biotization) with selected AM fungi to enhance their survival. It is also important for nursery managers and reforestation silviculturists to identify seedling attributes quantitatively linked to planting success and to an improved field response (Burdett 1983, 1990; Grossnickle and Folk 1993; Jacobs et al. 2005a; Haase 2008; Grossnickle and MacDonald 2018; Grossnickle et al. 2018). Seedling quality evaluation includes morphological quality based on physical attributes, and physiological quality based on metabolism. Both act as a proxy for interpreting the success of field establishment of the seedlings (Haase 2008). Therefore above- and below-ground morphological and physiological parameters can help to grade the quality of mycorrhizal walnut saplings seedlings with regard to their planting success.

\subsection{Survival of walnut seedlings after ex vitro acclimatization and field transplanting}

Due to the heterozygosity of walnut, the characteristics of agronomical interest of the chosen cultivar are not inherited via seed propagation (Sharma et al. 2003). Consequently, plant tissue culture plays a key role in mass propagation of high-quality walnut cultivars and rootstocks with desirable traits (Payghamzadeh and Kazemitabar 2011). However, micropropagated walnut plantlets first undergo restricted $\mathrm{Pi}$ nutrition that limits biomass production (Barbas et al. 1993) and further display poor survival during acclimatization to the soil environment (Hacket et al. 2010). During this period, plantlets need to adapt to greenhouse conditions with decreased humidity and low sugar availability relatively to in vitro growth conditions (Fortuna et al. 1992; Schubert and Lubraco 2000; Borkowska 2002). The leaves of micropropagated plantlets display poor cuticular wax development, a low chlorophyll content, and non-functional stomata (Rohr et al. 2003; Chandra et al. 2010). Those characteristics result in excessive transpiration rates leading to desiccation, reduced photosynthetic efficiency, and carbohydrate exhaustion before replenishment from photosynthesis. Earlier studies have highlighted a beneficial role of AM fungi during the ex vitro acclimatization (Azcón-Aguilar et al. 1992; Rai 2001), but to the best of our knowledge, it has been addressed only once for Juglans plantlets: Peixe et al. (2015) showed that inoculation with Glomus spp. did not improve ex vitro survival of $J$. regia $\times J$. hindsii rootstocks. In this context, it is noteworthy that (1) AM colonization during ex vitro development only takes place in young secondary roots (AzcónAguilar and Barea 1997) and (2) the rooting ability of micropropagated walnut plantlets is genotype-dependent (Dolcet-Sanjuan et al. 1996). Further research is needed to assess the potential of AM fungi to improve the ex vitro acclimatization of micropropagated walnut trees as related to their rooting pattern and mycorrhizal dependency.
Field-transplanted nursery trees also present variable degrees of transplant stress, described as the disruption of physiological functions in seedlings. Transplant shock is mainly caused by low nutrient availability resulting from poor rootsoil contact, low water porosity of suberized roots, and mechanical root damage (Rietveld 1989; Haase and Rose 1993; Grossnickle 2005). Nurseries and reforestation programs can greatly benefit from AM biotization for the growth and establishment of seedlings used in forestry (Cordell et al. 1987; Perry et al. 1987; Pagano and Cabello 2011; Szabó et al. 2014). Early inoculation of walnut trees with AM fungi can help them survive once transplanted (Table 3 ). This is especially mirrored by the calculation of the mycorrhizal response (MR) index (Plenchette et al. 1983) that represents the amount of plant gains from an AM fungal associate (Baon et al. 1993). A positive MR means that seedlings benefit from the AM symbiosis. A negative MR indicates that the costs of symbiosis for the plant exceed their benefits (Janos 2007). Table 3 notably shows that the MR of walnut in terms of survival reaches up to 53 and $75 \%$ in J. nigra and J. regia, respectively. Consequently, even though indigenous AM fungi are present in the soil, early inoculation of walnut saplings with selected AM strains protects them against transplant stress.

\subsection{Walnut seedling quality attributes}

Seedling quality assessment aims to quantify the morphological attributes of seedlings associated with vigorous growth and development (Wilson and Jacobs 2006). This involves a combination of several characteristics, including belowground and aboveground parameters (Jacobs et al. 2005a). As illustrated for J. nigra and J. regia (Table 3), morphological grading of walnut saplings shows that AM inoculation of walnut significantly improves root biomass, total length, and volume. The MR of walnut seedling lateral roots notably reaches $22 \%$ in $J$. nigra (Table 3). Although this is not a general trait of mycorrhizal roots (Hetrick et al. 1988), AM colonization increases the number of lateral roots in most hardwood species and enhances the resource uptake activity (Guo et al. 2008; Zadworny and Eissenstat 2011). Because rooting characteristics are not easily accessible, this has led to the identification of non-destructive measurements of aboveground parameters correlated to successful hardwood development.

The size of the root system and stem volume are an indicator of the seedling survival potential (Haase 2008). In mycorrhizal J. nigra (Table 3), positive MRs have been recorded for the root collar diameter of J. nigra (Table 3). Similar observations were done with stem biomass and height, which are usually used as a proxy of photosynthetic capacity (Haase 2008; Fajardo et al. 2014). Leaf count, area, and biomass were also significantly higher in inoculated seedlings than in the controls in J. nigra and in the timber species $J$. venezuelensis endemic to 


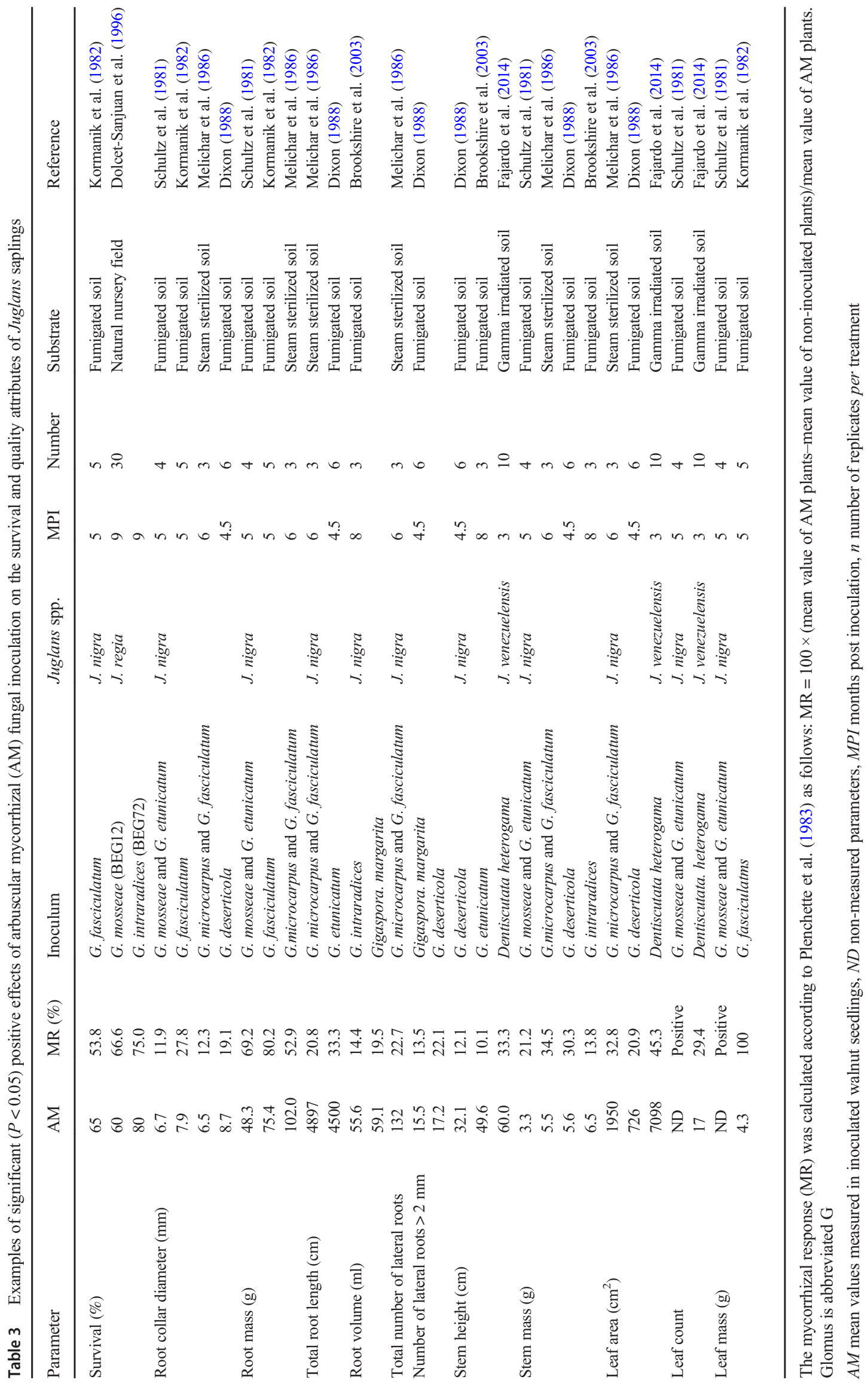


Venezuela (Table 3). Positive mycorrhizal responses recorded for walnut aboveground parameters (Table 3) have been ascribed to an increase in $\mathrm{C}$ assimilation by AM plants. More $\mathrm{C}$ is allocated to the leaves as a result of better nutrient availability to meet the growth demand (Fajardo et al. 2014). This was mirrored by increases in leaf $\mathrm{P}, \mathrm{N}$, and $\mathrm{K}$ concentrations of up to $35 \%$ following $J$. nigra and $J$. venezuenlis inoculation (Table 4). As illustrated in Fig. 4a-a principal component analysis (PCA) of the data reported by Dixon (1988) - (see Table 3), the developmental and nutritional values of walnut saplings are positively correlated to each other and to the mycorrhizal status of seedlings. This result holds especially true for the walnut $\mathrm{P}$ content and the number of lateral roots. A PCA of the results reported by Kormanik et al. (1982) (Table 3) also highlighted a positive correlation between the mycorrhizal status of walnut saplings, their survival and the total plant P content (Fig. 4b). Taken together, these results largely support that biotization with AM fungi benewalnut transplant success by increasing the number of lateral roots and plant P uptake. Multivariate analysis based on PCA also indicates that leaf area, stem height, and root collar diameter are among the non-destructive aboveground morphological parameters correlated to AM-mediated walnut field survival.

\subsection{Benefits are fungus- and host-dependent}

AM symbionts colonize a large number of host plant species (van der Heijden et al. 2015). Yet, the degree of root colonization by distinct AM inoculants does not correlate with the effects on the host plant. This result holds true for Juglans species, which do not respond in the same way to all AM fungal species (Schultz and Kormanik 1982; Dixon 1988; Fajardo et al. 2014). Total P nutrition in J. nigra was greater in response to colonization with a mixture of Glomus and Gigaspora species than with Glomus fasciculatum alone (Schultz and Kormanik 1982) (Table 5a). In J. venezuelensis, Dentiscutata heterogama outperformed Rhizophagus manihotis with longer roots, and higher shoot-to-root mass ratio, leaf mass ratio, leaf area ratio, and chlorophyll $a$ content. Although J. nigra roots were unequally colonized by distinct AM fungi (Table 5b), similar symbiotic outcome in terms of leaf and stem weights (Kormanik et al. 1982), root length and the number of lateral roots (Dixon 1988) were observed. The influence of the colonization of walnut roots by AM fungi of on gene expression patterns has not yet been done (Feddermann et al. 2010), but these results support the occurrence of functional diversity among AM symbionts not reflected by root colonization parameters.

Table 4 Examples of significant $(P<0.05)$ positive effects of arbuscular mycorrhizal (AM) fungal inoculation on the mineral nutrition of Juglans saplings

\begin{tabular}{|c|c|c|c|c|c|c|c|c|}
\hline $\begin{array}{l}\text { Sapling nutrient } \\
\text { concentration }(\mathrm{mg} / \mathrm{g})\end{array}$ & $\mathrm{AM}$ & $\begin{array}{l}\text { MR } \\
(\%)\end{array}$ & Inoculum & Juglans spp. & MPI & $\mathrm{n}$ & Substrate & Reference \\
\hline \multicolumn{9}{|l|}{ Phosphorus } \\
\hline Foliar & 0.26 & 19.3 & Dentiscutata heterogama & J. venezuelensis & 3 & 10 & $\begin{array}{l}\text { Gamma irradiated } \\
\text { soil }\end{array}$ & Fajardo et al. (2014) \\
\hline Foliar & 0.27 & 22.2 & Rhizophagus manihotis & & & & & \\
\hline Total & 0.69 & 21.7 & Glomus fasciculatum & J. nigra & 5 & 5 & Fumigated soil & $\begin{array}{l}\text { Schultz and Kormanik } \\
\text { (1982) }\end{array}$ \\
\hline Total & 0.84 & 35.7 & $\begin{array}{l}\text { Glomus and Gigaspora } \\
\text { species }\end{array}$ & & & & & \\
\hline Total & 1.20 & 33.3 & Gigaspora margarita & J. nigra & 4.5 & 6 & Fumigated soil & Dixon (1988) \\
\hline Total & 1.30 & 38.5 & Glomus deserticola & & & & & \\
\hline \multicolumn{9}{|l|}{ Nitrogen } \\
\hline Foliar & 7.9 & 35.4 & Rhizophagus manihotis & J. venezuelensis & 3 & 10 & $\begin{array}{l}\text { Gamma irradiated } \\
\text { soil }\end{array}$ & Fajardo et al. (2014) \\
\hline Total & 2.1 & 23.8 & Gigaspora margarita & J. nigra & 4.5 & 6 & Fumigated soil & Dixon (1988) \\
\hline Total & 2.1 & 23.5 & Glomus deserticola & & & & & \\
\hline \multicolumn{9}{|l|}{ Potassium } \\
\hline Foliar & 4.6 & 15.7 & Dentiscutata heterogama & J. venezuelensis & 3 & 10 & $\begin{array}{l}\text { Gamma irradiated } \\
\text { soil }\end{array}$ & Fajardo et al. (2014) \\
\hline Foliar & 4.2 & 7.4 & Rhizophagus manihotis & & & & & \\
\hline Total & 5.7 & 28.1 & Gigaspora margarita & J. nigra & 4.5 & 6 & Fumigated soil & Dixon (1988) \\
\hline Total & 6.4 & 35.9 & Glomus etunicatum & & & & & \\
\hline
\end{tabular}

The mycorrhizal response (MR) was calculated according to Plenchette et al. (1983) as follows: MR = $100 \times$ (mean value of AM plants-mean value of non-inoculated plants)/mean value of AM plants

$A M$ mean values measured in inoculated walnut, $N D$ non-measured parameters, MPI months post inoculation, $n$ number of replicates per treatment 
a

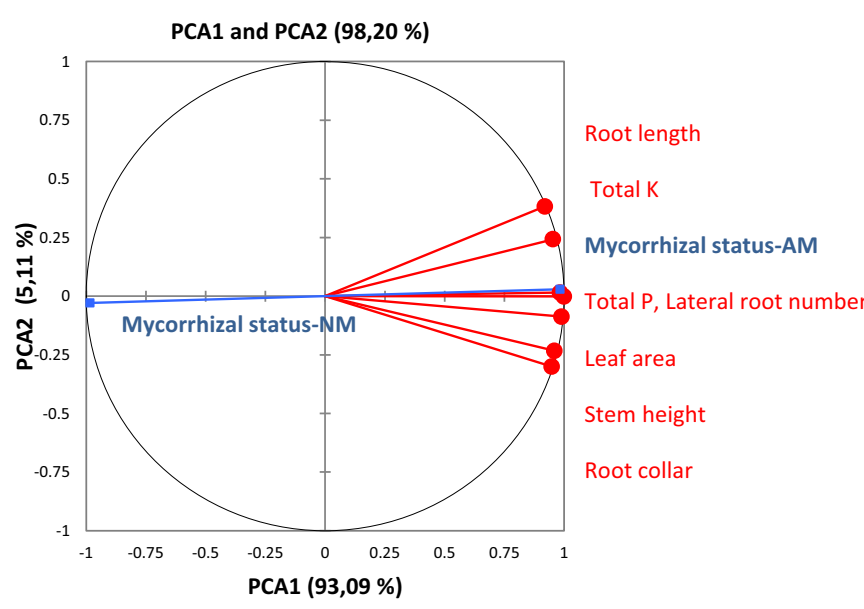

Fig. 4 Effect of mycorrhiza on walnut development and the mineral nutrient content. Growth and nutritional parameters of walnut seedlings under contrasted mycorrhizal statuses, as reported by a Dixon (1988) and b Kormanik et al. (1982), were compared by principal component

Besides the AM fungal isolate, the walnut cultivar also impacts seedling quality attributes and the degree of mycorrhizal colonization of J. nigra seedlings (Dixon 1988; Brookshire et al. 2003). Likewise, the seedling genotype/ mycorrhiza interaction was significant for root collar diameter, leaf area, root weight and length, and colonization percentage, indicating a strong host-symbiont interaction effect (Dixon 1988). Therefore, walnut responses to mycorrhization vary with the nature of the fungal and plant partners, and also with soil properties (Herrera-Peraza et al. 2011). As a result, one could recommend selecting an effective mycorrhizal inoculant to improve walnut seedling quality attributes based on bioassays integrating the morphological and physiological responses of each walnut cultivar.

\section{Arbuscular mycorrhizal fungi in walnut agroforestry systems}

Agroforestry is a land-use practice that involves planting woody perennials with other plants in a same area, simultaneously or sequentially (Nair 1993; Garrity 2012; Waldron et al. 2017). Relatively to tree monoculture, walnut agroforestry is based on the management of plant interactions to maximize tree growth and nut/timber productivity (Dupraz et al. 1999; Mary et al. 1998; Newman 2006; Malézieux et al. 2009; Rehnus et al. 2013). Mixed cropping has been documented for several walnut species and cultivars, including the common walnut $(J$. regia), various $J$. nigra $\times J$. regia cultivars, the American black walnut (J. nigra), and J. mandshurica, the Manchurian walnut (Gordon and Williams, 1991; b

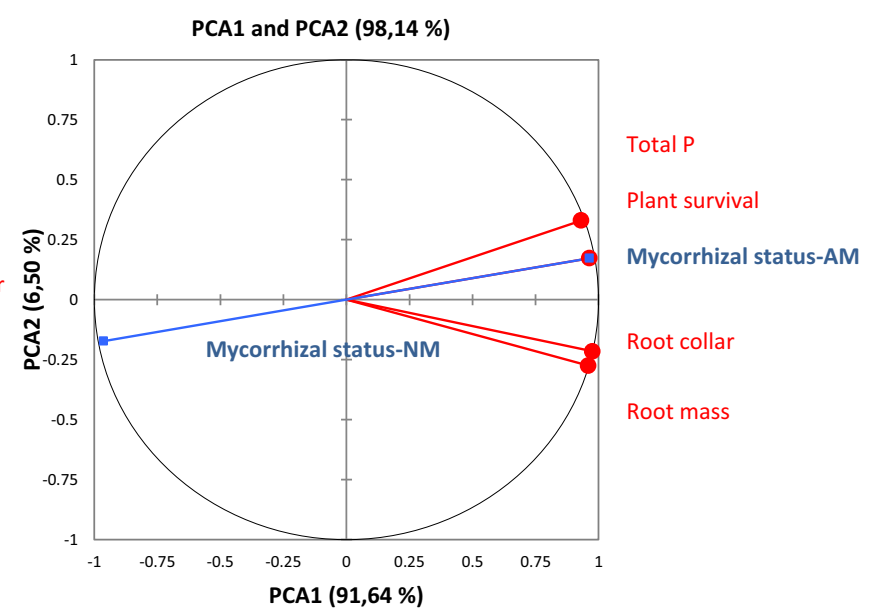

analysis, with PC1 explaining 93.09 and $91.64 \%$ of variance, respectively. AM and NM, mycorrhizal and non-mycorrhizal saplings, respectively

Mosquera-Losada et al. 2009; Mohni et al. 2009; Yang et al. 2010; Salahuddin et al. 2018). Because fine roots are key for acquiring essential nutrients and water from the soil (McCormack et al. 2015), the sustainability of mixed-species plots largely depends on belowground complementary and competitive interactions (van Noordwijk et al. 1996; Jose et al. 2006). For mycotrophic hardwood species used in agroforestry, including Juglans spp., soil nutrient acquisition depends on rooting traits and is also mediated by AM fungi (Janos 2007; de Kroon et al. 2012). The role of these fungi in mixed plant communities is amplified by their low host specificity, so that extra-radical hyphae connect the roots of different plant species to form a common mycelial network (CMN). CMNs linking co-cultivated plant species can mediate facilitation via nutrient transfer (Martins and Cruz 1998; Fitter et al. 1998; He et al. 2003; Leake et al. 2004; Hauggaard-Nielsen and Jensen 2005; van der Heijden and Horton 2009; Walder et al. 2012; Fellbaum et al., 2014; Gorzelak et al. 2015; Montesinos-Navarro et al. 2016), but also interference competition by releasing allelopathic chemicals that directly inhibit growth (Barto et al. 2012; Salahuddin et al. 2018). Understanding positive and negative feedbacks between mixed walnut plantations and AM fungi is therefore of critical importance in the management of mixed cropping systems.

\subsection{Arbuscular mycorrhizal inoculum density and diversity in walnut agroforestry systems}

To form mycorrhizas, plant roots need to come into contact with AM fungal propagules - soil-borne spores, hyphae, or 
root fragments bearing fungal structures (internal hyphae or vesicles). These propagules represent the quantity of AM inoculum in the soil, i.e., the population of AM fungi (Plenchette et al. 2005). Compared with monoculture systems, the presence of trees in an agricultural system enhances AM fungal propagule abundance and diversity (Ingleby et al. 2007; Chifflot et al. 2009; de Carvalho et al. 2010; Bainard et al. 2011). Intercropping has been proposed to draw intermediate income before the plantation reaches economic maturity (van Sambeek and Garrett 2004; Mohni et al. 2009; van Sambeek 2017; Wolz and DeLucia 2019). In this case, the intercrop-winter cereals (Triticum spp), alfafa (Medicago sativa), soybean (Glycine max), or summer crops (e.g., maize) - is the only income during the first 5 to 10 years; then, both trees and intercrops produce simultaneously (Mary et al. 1998; Huasen et al. 2014).

As woody perennial walnut roots allow for the year-in year-out persistence of AM propagules, intercropping with mycotrophic species increases mycorrhiza formation in the soil and thus the abundance of AM fungi populations. A higher AM spore density was observed in wheat roots intercropped with walnut than in crop monoculture (CASDAR 2012). As previously indicated in other agroforestry systems, walnut trees act as reservoirs of AM fungi for crops or other annual vegetation (Ingleby et al. 2007; Kumar et al. 2007; Shukla et al. 2012). Walnutwheat agroforestry plots displayed increased soil organic matter associated with a higher microbial biomass than monoculture plots (CASDAR 2012). Both the number and diversity of $\mathrm{AM}$ spore were enhanced in the deep horizons of walnut-wheat agroforestry fields relative to conventional monoculture (PIRAT 2012). When associated to deep walnut tree roots, AM fungi can increase the mycorrhiza-mediated uptake of soil nutrients, and thereby contribute to the nutrition of the co-cultivated species (Simard and Durall 2004; de Carvalho et al. 2010). Because mycorrhizal types differ in their physiological traits, which facilitates dissimilar soil nutrient uptake processes, the presence and diversity of fungal associations should increase resource partitioning among the different plant species with which they associate (Ferlian et al. 2018). AM fungi associated with maize and walnut roots in a same field were recently found to differ in diversity (van Tuinen et al. 2020). Concomitantly, the analysis of ${ }^{13} \mathrm{C}$ from an $\mathrm{AM}$ mycelium taken from the surrounding environment of intercropped walnut and maize roots indicated that part of the carbon derived from walnut trees could be transferred to maize plants (van Tuinen et al. 2020). In summary, these results underline that walnuttree-based intercropping enhances AM fungal richness compared with monoculture systems and that AM fungi participate in the redistribution of nutrients between tree and crop roots.

\subsection{Arbuscular mycorrhizal dependency in walnut agroforestry systems}

As a genotypic property of plants, mycorrhizal dependency varies according to growing conditions and nutrient availability (Plenchette et al. 2005), with fine-root biomass generally lower in fertilized stands (Li et al. 2019). Compared with other deciduous angiosperms, walnut trees have great needs mainly in $\mathrm{N}, \mathrm{P}$, and $\mathrm{K}$, and a relatively narrow range of soil conditions beneficial to their growth (Simorte et al. 2001; Bhattarai and Tomar 2009; Mohni et al. 2009; Gauthier and Jacobs 2011). Based on analyses of nutrient levels in healthy leaf samples and comparisons with standards recognized to be non-limiting for plant growth, nutrient deficiency in the genus Juglans occurs for leaf $\mathrm{N}, \mathrm{P}$, and $\mathrm{K}$ contents below 22, 1 , and $12 \mathrm{~g}$ per $\mathrm{kg}$ of dry matter, respectively (Table 6). Fertilization enhances walnut value (Brockley 1988; Jones et al. 1995; Jacobs et al. 2005b; Salifu et al. 2006). For example, annual applications of $\mathrm{N}$ and $\mathrm{P}$ at rates of $310 \mathrm{~kg}$ and $620 \mathrm{~kg}$ per ha for 4 years significantly increased $J$. nigra nut production and leaf nutrient levels (Ponder 1998). Supplying plants with growthlimiting nutrients is one of the major factors in the control of fruit yield and quality. However, plants have long been known to respond to long-term soil inorganic $\mathrm{P}$ or $\mathrm{N}$ levels in the range of $100 \mathrm{mg}$ or more per $\mathrm{kg}$ of soil, with inhibition of AM symbiosis development (Baylis 1967; Graham et al. 1981; Wipf et al. 2019 and references therein). As regards Juglans spp., a shift from $14 \mathrm{~kg}$ to $112 \mathrm{~kg}$ of both $\mathrm{N}$ and $\mathrm{P}$ per ha significantly reduced $J$. nigra root AM colonization intensity and the percentage of arbuscules (Schultz et al. 1981). In the same order of magnitude, mycorrhiza-induced growth benefits for black walnut were only reported for soil $\mathrm{P}$ levels below $170 \mathrm{~kg}$ per ha (Kormanik 1985). Assuming that the total weight of 1 ha of soil to a depth of $30 \mathrm{~cm}$ is approximately $3.9 .10^{6} \mathrm{~kg}$ (Verheye 2006), P fertility above $44 \mathrm{mg}$ per $\mathrm{kg}$ of soil may inhibit AM colonization of walnut roots, decrease benefits of mycorrhiza, and enhance plant production costs for growers.

Besides chemical fertilization, the choice of the co-culture in walnut agroforestry has consequences on the mycorrhizal dependency of Juglans spp. The study of the acclimation of fine-root systems to long-term interspecific competition between larch (Larix gmelinii) and J. mandshurica trees showed that walnut displayed lower plasticity than larch as regard the branching patterns of the terminal root orders (Salahuddin et al. 2018). The arbuscular mycorrhizal colonization rates of the Manchurian walnut terminal root orders were also significantly lower $(-28 \%)$ in the mixed plantation than in monoculture stands. The authors therefore proposed that the changes in mycorrhizal infection rates under interspecific competition are related to different nutrient availabilities, especially $\mathrm{P}$. This hypothesis was indirectly supported by decreased specific root length and respiration rates of first-order 
walnut roots when grown in mixture with larch (Salahuddin et al. 2018). Consistently, Chen et al. (2001) showed that larch roots improved the mobilization of rhizospheric rock phosphate more efficiently. This resulted in an increased available $\mathrm{P}$ content in the rhizosphere of $J$. mandshurica in mixed plantation relatively to monoculture. In Manchurian walnut, higher $\mathrm{P}$ availability in mixed plantation thus leads to a decreased investment into mycorrhizal symbionts (Salahuddin et al. 2018).

As plant-produced $\mathrm{C}$ is exchanged for AM fungusacquired soil mineral nutrients, factors that negatively affect photosynthesis can reduce AM plant root colonization, soil mineral nutrient uptake, and thus plant mycorrhizal dependency (Heinemeyer et al. 2006; Gavito et al. 2019). At the treecrop interface, light is the main limiting factor for the growth of understory vegetation in agroforestry systems, where trees reduce the availability of light to intercrops (Reynolds et al. 2007). High light intensities and long day lengths improve AM colonization and spore production in many plants (Moses et al. 2013; Konvalinková and Jansa 2016). On the contrary, tree shade, low light intensity, short day lengths, and defoliation reduce arbuscular development and spore formation because the photosynthate supply to the AM fungus decreases (Kumar et al. 2007; Shukla et al. 2009). In crop monoculture, tree shade has been evoked as the main factor responsible for the reduced AM spore density observed in agroforestry stands in spring when barley was intercropped with 30year-old J. nigra and J. regia trees (CASDAR 2012). Overall, these studies indicate that AM mycorrhizal dependency is responsive to seasonal variation and that tree canopy management is likely to increase the development of AM fungi in walnut intercropping systems.

\subsection{Arbuscular mycorrhizal fungal and interference competition in walnut agroforestry systems}

Many trees of the Juglandaceae family, including $J$. regia, J. nigra, J. cinerea, J. ailantifolia, and J. mandshurica, produce juglone (5-hydroxy-1,4-naphthoquinone), an amber-colored phenolic compound poisonous to sensitive plants (Dana and Lerner 1990; Jose and Gillespie 1998; Willis 2000; Yang et al. 2010). The presence of walnut trees has a natural inhibiting effect on several species and acts as a growth-limiting factor in agroforestry systems (Strugstad and Despotovski 2012). In some typical walnut intercrops, including Zea mays and Glycine max, juglone decreases and even inhibits shoot and root growth rates, leaf photosynthesis, transpiration, respiration, and stomatal conductance. An inhibition threshold of $10^{-4} \mathrm{M}(3 \mathrm{mg}$ extractable juglone per $\mathrm{kg}$ of soil) was reported for maize and soybean (Hejl et al. 1993; Jose and Gillespie 1998; von Kiparski et al. 2007 , and references therein). The growth of the $\mathrm{N}_{2}$-fixing walnut companion crop black alder and autumn-olive was depressed when hydroponically grown in solutions containing juglone at $10^{-5} \mathrm{M}$ in chloroform (Rietveld 1981).

Potential juglone abundance estimated in walnut leaves, hulls, and roots ranges from less than $0.1 \%$ to $5 \%$ dry weight depending on when the samples were taken in the growing season and on the extraction techniques (Willis 2000 and citations within). Juglone gets into the soil through rhizodeposition and leaching out of decomposing leaves, hulls, fruit, or bark (Rietveld 1983; Duroux et al. 1998; Appleton et al. 2014). Juglone release affects neighboring plants up to distances ranging from $4 \mathrm{~m}$ (Jose and Gillespie 1998) to $27 \mathrm{~m}$ (Massey 1925) from the trunk of walnut trees depending on their age. Toxicity persists after tree removal for up to 1 year because juglone is persistent in the soil (Strugstad and Despotovski 2012). However, juglone could easily be degraded by polyphenol oxidase, cellulose-decomposing microorganisms or the bacterium Pseudomonas putida (Yang et al. 2010 and references therein). As documented in root exudates of larch intercropped with $J$. mandshurica, the increased soil microbial populations and enzyme activities in a mixed-species plantation could lead to rapid degradation of juglone (Yang et al. 2010). Consistently, Manchurian walnut trees release a large quantity of juglone into the rhizosphere, but very little juglone reaches the bulk soil (Sun et al. 2013). These results point to soil microorganisms as an important determinant of the fate and activity of allelochemicals (Inderjit 2005).

AM fungal connections transport purified or naturally released juglone (Achatz and Rillig 2014; Achatz et al. 2014). The authors found an increase in juglone transport when a mycorrhizal hyphal network was present, resulting in reduced growth of the target tomato plants. The amount of extractable soil juglone in the tomato root compartment was $271 \%$ higher when the soil was connected to the walnut leaf litter by mycorrhizal hyphae (Achatz and Rillig 2014). Because juglone is slightly hydrophobic, its movement through the AM mycelium most likely occurs via water flow along hyphae (Achatz and Rillig 2014; Achatz et al. 2014). Overall, these studies underline that AM-hypha-mediated transport of juglone contribute to the allelopathic effect of walnut in agroforestry systems, but may be modulated by the presence of rhizosphere microbial communities able to degrade juglone.

\section{Conclusion}

Currently available knowledge indicates that walnut trees can benefit from the development of a functional AM symbiosis. Mycorrhizal inoculation notably helps Juglans species to establish and improves planting performances in terms of plant survival and development. The effect of mycorrhization depends on the nature of the plant-fungus couple. As the coarse root architecture of walnut trees has a limited intrinsic ability to absorb soil nutrients, plant $\mathrm{N}$ and $\mathrm{P}$ concentrations are higher in AMinoculated walnut seedlings than in non-mycorrhizal plants. 


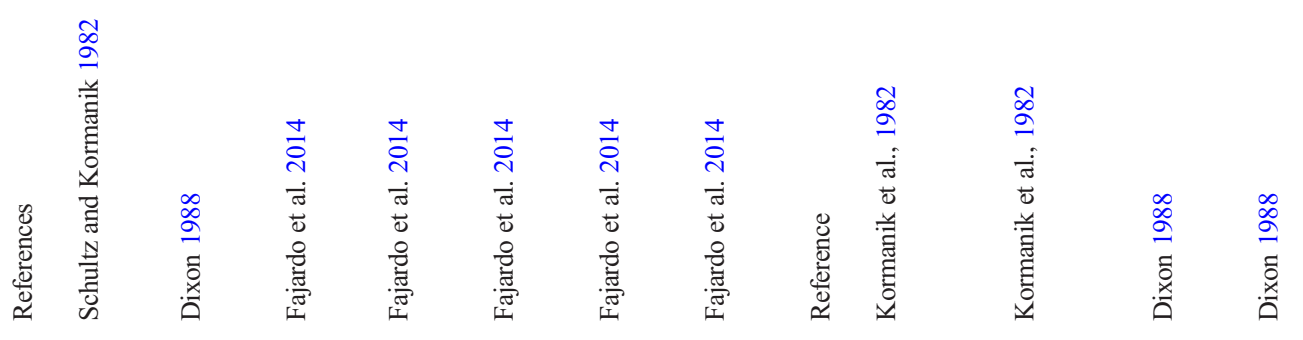

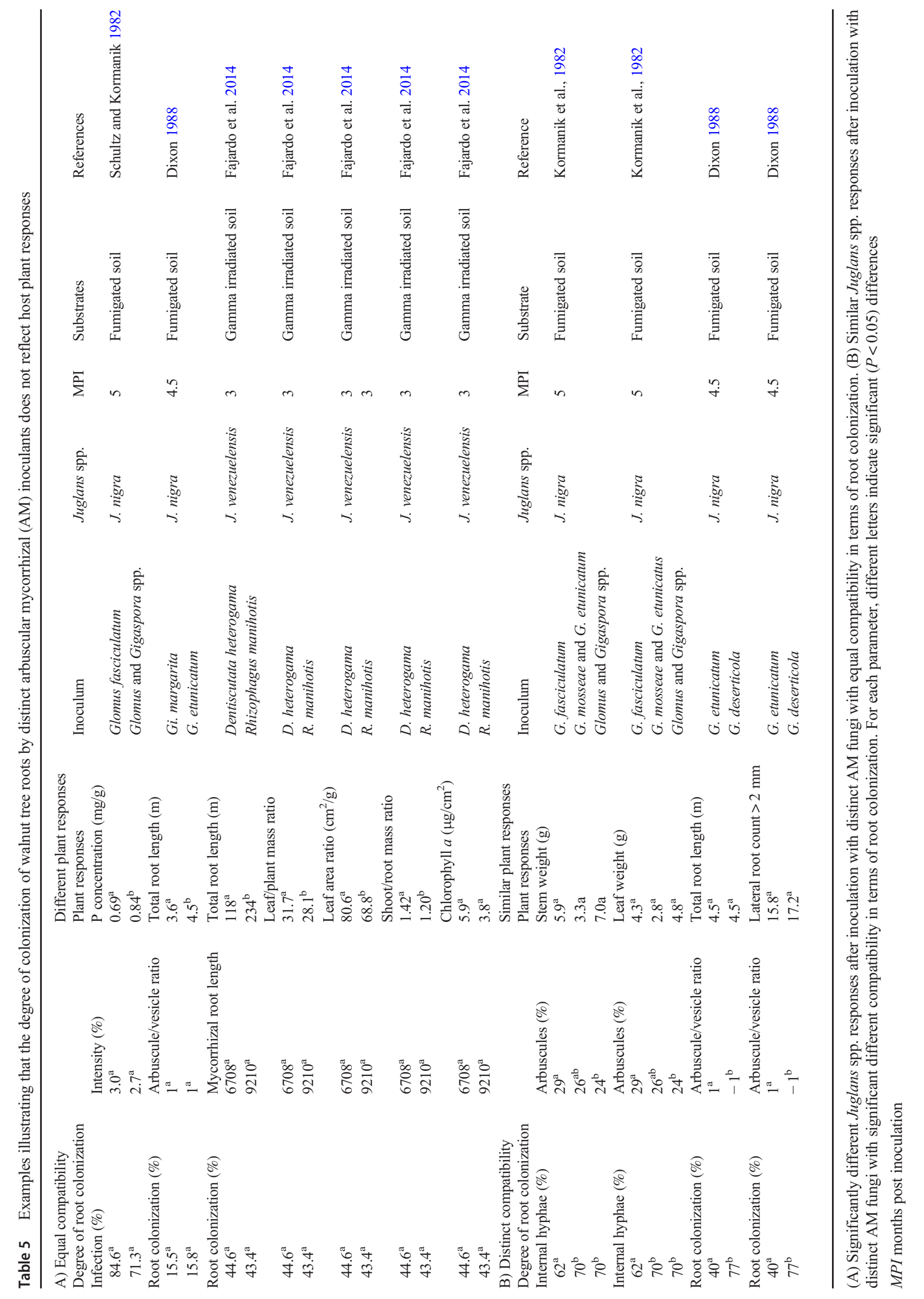


Table 6 Recommended leaf contents (\% dry weight) of essential mineral macronutrients for adequate growth of Juglans spp, updated from Blinn and Bucker (1989) and Ponder (2004). ND corresponds to not determined

\begin{tabular}{llllllll}
\hline & $\mathrm{N}$ & $\mathrm{P}$ & $\mathrm{K}$ & $\mathrm{Ca}$ & $\mathrm{Mg}$ & $\mathrm{S}$ & \\
\hline Juglans spp & $2.2-3.2$ & $0.1-0.3$ & 1.2 & 1.0 & 0.3 & $\mathrm{ND}$ & Beutel et al. (1976) \\
& $2.2-3.2$ & $0.14-0.3$ & $1.2-1.7$ & $>1.0$ & $>0.3$ & $\mathrm{ND}$ & Beede et al. (2011) \\
J. californica (California walnut) & $>2.5$ & $>0.11$ & $>1.00$ & $\mathrm{ND}$ & $>0.30$ & $\mathrm{ND}$ & Serr (1960) \\
J. cinerea (Butternut) & 1.79 & 0.44 & 0.82 & 1.11 & 0.72 & 0.25 & Gerloff et al. (1964) \\
J. regia (Persian or English walnut) & $2.6-3.5$ & $0.19-0.24$ & $1.3-2.3$ & $\mathrm{ND}$ & $0.19-0.35$ & $\mathrm{ND}$ & Kopinga and van den Burg (1995) \\
& $2.2-2.6$ & $0.12-0.20$ & $1.00-1.75$ & $0.75-20.00$ & $0.20-0.75$ & $\mathrm{ND}$ & Smith (2003) \\
& $2.31-2.80$ & $0.14-0.50$ & $1.21-2.50$ & $1.11-2.50$ & $0.25-0.60$ & $0.11-0.20$ & Olsen (2006) \\
J. nigra (Black walnut) & 1.74 & 0.46 & 1.98 & 3.3 & 0.5 & 0.01 & McHargue and Roy (1932) \\
& $2.0-2.6$ & $0.10-0.25$ & $0.75-1.30$ & $0.50-1.10$ & $0.15-0.45$ & $0.05-0.25$ & Phares and Finn (1971) \\
& $2.1-2.6$ & $0.15-0.21$ & $1.05-2.00$ & $\mathrm{ND}$ & $0.21-.30$ & ND & Kopinga and van den Burg (1995) \\
& 1.92 & 0.54 & 1.48 & 0.95 & 1.01 & 0.14 & Gerloff et al. (1964) \\
& $2.47-2.98$ & $0.16-0.24$ & $1.32-1.47$ & $1.9-2.0$ & $0.51-0.64$ & $0.15-0.16$ & Mills and Jones (1996) \\
& $2.01-5.00$ & $0.26-.0 .39$ & $2.10-4.00$ & $0.51-1.00$ & $0.26-2.50$ & $0.22-0.55$ & Jacobs and Seifert (2004) \\
& $2.2-3.5$ & $0.20-0.33$ & $0.9-2.0$ & $1.2-2.5$ & $0.3-0.6$ & ND & Reid et al. (2009) \\
\hline
\end{tabular}

Therefore, walnut trees benefit from symbiosis through the mycorrhizal network. However, despite the release of draft reference genomes for several Juglans spp. (https://harwoodgenomics.org; https://treegenesdb.org), no data is presently available on AMspecific walnut gene expression patterns. This also holds true as to the quantification of mycorrhizal symbiotic efficiency in walnut trees, i.e., $\mathrm{C}$ gained via the growth response to mycorrhizal colonization minus $\mathrm{C}$ spent to support the fungus. Fertilization was found to control the degree of AM colonization of walnut roots. This suggests that according to their nutrient status, walnut trees can stop allocating $\mathrm{C}$ to the symbiont when the cost of fungal maintenance exceeds the nutrient benefit. As an obvious implication in the context of walnut agricultural practices, fertilization with phosphate decreases AM colonization of walnut trees and reduces AM fungal community richness. However, in low-input agroforestry systems, deeply rooted mycorrhizal walnut trees act as reservoirs of AM fungal propagules for the surrounding vegetation. The existence of mycelial networks gathering trees and annual companion crops enhances complementarities in resource-capture strategies. While the transport of the allelochemical juglone by AM mycelial networks grown from walnut roots has been documented, no data is presently available on the role of CMNs in mediating $\mathrm{N}$ and $\mathrm{P}$ trophic plant-plant facilitation in walnut agroforestry. Finally, in the context of rootstock breeding and production, AM symbiosis may also find applications by potentially improving walnut plantlet acclimatization and adaptation to environmental conditions, including increased tolerance to various pests.

Acknowledgements We would like to thank the editorial board and the anonymous reviewers for their valuable suggestions. We thank D. Jubault for the drawings. We thank Annie Buchwalter for editing this manuscript. We thank D Wipf and PE Courty for their input in the $\mathrm{PhD}$ proposal writing. Emma Mortier's PhD thesis was funded by The French Ministry of Agriculture and benefited from a collaboration with L Jouve's company.

\section{Compliance with ethical standards}

Conflict of interest The authors declare that they have no conflict of interest.

Authors' contributions Conceptualization: O.L., F.M-L., E.M. and G.R..; Writing of the original draft: O.L., F.M-L., E.M. and G.R.; Writing, review and editing: O.L., F.M-L., E.M. and G.R.

Open Access This article is licensed under a Creative Commons Attribution 4.0 International License, which permits use, sharing, adaptation, distribution and reproduction in any medium or format, as long as you give appropriate credit to the original author(s) and the source, provide a link to the Creative Commons licence, and indicate if changes were made. The images or other third party material in this article are included in the article's Creative Commons licence, unless indicated otherwise in a credit line to the material. If material is not included in the article's Creative Commons licence and your intended use is not permitted by statutory regulation or exceeds the permitted use, you will need to obtain permission directly from the copyright holder. To view a copy of this licence, visit http://creativecommons.org/licenses/by/4.0/.

\section{References}

Achatz M, Rillig MC (2014) Arbuscular mycorrhizal fungal hyphae enhance transport of the allelochmical juglone in the field. Soil Biol Biochem 78:76-82. https://doi.org/10.1016/j.soilbio.2014.07.008

Achatz M, Morris EK, Müller F, Hilker M, Rillig MC (2014) Soil hyphamediated movement of allelochemicals: arbuscular mycorrhizae extend the bioactive zone of juglone. Funct Ecol 28:1020-1029. https://doi.org/10.1111/1365-2435.12208 
Amaral JS, Seabra RM, Andrade PB, Valentão Ṕ, Pereira JA, Ferreres F (2004) Phenolic profile in the quality control of walnut (Juglans regia L.) leaves. Food Chem 88:373-379. https://doi.org/10.1016/ j.foodchem.2004.01.055

Appleton B, Berrier R, Harris R, Alleman D, Swanson L (2014) The walnut tree: allelopathic effects and tolerant plants. Virginia Tech Dept Hortic, Norfolk VCE, and Chesapeake VCE. Virginia Cooperative Extention http://hdl.handle.net/10919/48768. Online document. Accessed 18 October 2019

Arya A, Arya C, Misra R (2010) Mechanism of action in arbuscular mycorrhizal symbionts to control fungal diseases. In: Arya A, Perello AE (eds) Management of fungal plant pathogens. CABI, pp 171-182

Avanzato D, McGranahan GH, Vahdati K, Botu M, Iannamico L, van Assche J (2014) Following walnut footprints (Juglans regia L.): cultivation and culture, folklore and history, traditions and uses. Scr Horticult 17 Leuven

Azcón-Aguilar C, Barea JM (1997) Applying mycorrhiza biotechnology to horticulture: significance and potentials. Sci Hortic 68:1-24. https://doi.org/10.1016/S0304-4238(96)00954-5

Azcón-Aguilar C, Barceló A, Vidal MT et al (1992) Further studies on the influence of mycorrhizae on growth and development of micropropagated avocado plants. Agronomie 12:837-840. https:// doi.org/10.1051/agro:19921017

Bago B, Azcon-Aguilar C, Goulet A et al (1998) Branched absorbing structures (BAS): a feature of the extraradical mycelium of symbiotic arbuscular mycorrhizal fungi. New Phytol 139:375-388. https:// doi.org/10.1046/j.1469-8137.1998.00199.x

Bailey LH, Bailey EZ (1976) Hortus, third edn. Macmillan, New York

Bainard LD, Klironomos JN, Gordon AM (2011) Arbuscular mycorrhizal fungi in tree-based intercropping systems: a review of their abundance and diversity. Pedobiol 54:57-61. https://doi.org/10.1016/j. pedobi.2010.11.00

Baon JB, Smith SE, Alston AM (1993) Mycorrhizal responses of barley cultivars differing in P efficiency. Plant Soil 157:97-105. https://doi. org/10.1007/BF000387

Barbas E, Chaillou S, Cornu D et al (1993) Orthophosphate nutrition of in vitro propagated hybrid walnut (Juglans nigra $\mathrm{x}$ Juglans regia) trees: $\mathrm{Pi}\left({ }^{32} \mathrm{Pi}\right)$ uptake and transport in relation to callus and shoot development. Plant Physiol Biochem 31:41-49

Barto EK, Weidenhamer JD, Cipollini D, Rillig MC (2012) Fungal superhighways: do common mycorrhizal networks enhance belowground communication? Trends Plant Sci 17:633-657. https://doi. org/10.1016/j.tplants.2012.06.007

Bates TR, Lynch JP (2001) Root hairs confer a competitive advantage under low phosphorus availability. Plant Soil 236:243-250. https:// doi.org/10.1023/A:1012791706800

Baylis GTS (1967) Experiments on the ecological significance of phycomycetous mycorrhizas. New Phytol 66:231-243. https://doi.org/10. 1111/j.1469-8137.1967.tb06001.x

Baylis GTS (1975) The magnolioid mycorrhiza and mycotrophy in root systems derived from it. In: Sanders FE, Mosse B, Tinker PB (eds) Endomycorrhizas. Academic, London, pp 373-389

Beede RH, Brown PH, Kallsen C, Weinbaum SA (2011) Diagnosing and correcting nutrient deficiencies. Fruit and Nutrition Research and Information Centre, University of California

Bender DA, Bender AE (2005) A dictionary of food and nutrition. Oxford University Press, Oxford. https://doi.org/10.1093/acref/ 9780199234875.001.0001

Bender SF, Wagg C, van der Heijden MGA (2016) An underground revolution: biodiversity and soil ecological engineering for agricultural sustainability. Trends Ecol Evol 31:440-452. https://doi.org/ 10.1016/j.tree.2016.02.016

Bernard A, Lheureux F, Dirlewanger E (2018) Walnut: past and future of genetic improvement. Tree Genet Genomes 14:1. https://doi.org/10. 1007/s11295-017-1214-0
Beutel J, Uriu K, Lilleland O (1976, 1879) Leaf analysis for California deciduous fruits. In: Reisenauer HM (ed) Soil and plant-tissue testing in California. University of California Cooperative Extension Bulletin, pp 15-17 http://www.ucanr.edu/sites/fruitreport/files/ 93308.pdf. Online document. Accessed 18 October 2019

Bhattarai B, Tomar C (2009) Effect of integrated nutrient management on leaf nutrient status of walnut (Juglans regia L.). Nepal J Sci Technol 10:63-67. https://doi.org/10.3126/njst.v10i0.2825

Blinn C, Bucker E (1989) Normal foliar nutrient levels in North American forest trees. Station Bulletin 590-1989 (Item No. ADSB-3762). Minnesota Agricultural Experiment Station, St Paul

Bonfante P, Venice F (2020) Mucoromycota: going to the roots of plantinteracting fungi. Fungal Biol Rev 34:100-113. https://doi.org/10. 1016/j.fbr.2019.12.003

Borkowska B (2002) Growth and photosynthetic activity of micropropagated strawberry plants inoculated with endomycorrhizal fungi (AMF) and growing under drought stress. Acta Physiol Plant 24:365-370. https://doi.org/10.1007/s11738002-0031-7

Bowen G, Rovira A (1999) The rhizosphere and its management to improve plant growth. Adv Agron 66:1-102. https://doi.org/10.1016/ S0065-2113(08)60425-3

Brockley RP (1988) The effects of fertilization on the early growth of planted seedlings: a problem analysis. Forest Resource Development Agreement Rep. 011. B.C. Ministry of Forests, Victoria

Brookshire BL, Garrett HE, Robison TL (2003) Effects of vesiculararbuscular mycorrhizae and seed source on nursery-grown black walnut seedlings. In: van Sambeek JW, Dawson JO, Ponder F Jr, Loewenstein EF, Fralish JS (eds) Proceedings of the 13th Central Hardwood Forest Conference, Gen. Tech. Rep. NC-234. Department of Agriculture, Forest Service, North Central Research Station, St. Paul, pp 468-475. http://www.fs.usda.gov/treesearch/ pubs/15826. Online document. Accessed 18 October 2019

Brundrett MC (1991) Mycorrhizas in natural ecosystems. Adv Ecol Res 21:171-313. https://doi.org/10.1016/S0065-2504(08)60099-9

Brundrett MC (2002) Coevolution of roots and mycorrhizas of land plants. New Phytol 154:275-304. https://doi.org/10.1046/j.14698137.2002.00397.x

Brundrett MC (2009) Mycorrhizal associations and other means of nutrition of vascular plants: understanding the global diversity of host plants by resolving conflicting information and developing reliable means of diagnosis. Plant Soil 320:37-77. https://doi.org/10.1007/ s11104-008-9877-9

Brundrett MC, Kendrick WB (1988) The mycorrhizal status, root anatomy and phenology of plants in a sugar maple forest. Can J Bot 66: 1153-1173. https://doi.org/10.1139/b88-166

Bücking H, Kafle A (2015) Role of arbuscular mycorrhizal fungi in the nitrogen uptake of plants: current knowledge and research gaps. Agronomy 5:587-612. https://doi.org/10.3390/agronomy5040587

Buée M, De Boer W, Martin F et al (2009) The rhizosphere zoo: an overview of plant-associated communities of microorganisms, including phages, bacteria, archaea, and fungi, and of some of their structuring factors. Plant Soil 321:189-212. https://doi.org/10.1007/ s11104-009-9991-3

Burdett AN (1983) Quality control in the production of forest planting stock. For Chron 59:132-138. https://doi.org/10.5558/tfc59132-3

Burdett AN (1990) Physiological processes in plantation establishment and the development of specifications for forest planting stock. Can J For Res 20:415-427. https://doi.org/10.1139/x90-059

Carpio LA, Davies FT, Arnold MA (2003) Effect of commercial mycorrhiza on growth, survivability, and subsequent landscape performance of selected container grown ornamental nursery crops. J Environ Hortic 21:190-195. https://doi.org/10.24266/0738-289821.4.190 
de Carvalho AMX, de Castro TR, Cardoso IM et al (2010) Mycorrhizal associations in agroforestry systems. In: Dion P (ed) Soil biology and agriculture in the tropics, soil biology 21. Springer-Verlag, Berlin Heidelberg, pp 185-208. https://doi.org/10.1007/978-3-64205076-3 9

CASDAR (2012) Améliorer l'Efficacité Agro-environnementale des Systèmes Agroforestiers. http://www.agroforesterie.fr/CASDAR/ 20092011/documents/Casdar-agroforesterie-2009-2011-3.2-3.3-et3.4-RAPPORT-final_2012_CASDAR-action-sol.pdf. Online document. Accessed 18 October 2019

Chandra S, Bandopadhyay R, Kumar V, Chandra R (2010) Acclimatization of tissue cultured plantlets: from laboratory to land. Biotechnol Lett 32:1199-1205. https://doi.org/10.1007/s10529. 010-0290-0

Chen Y, Han S, Shi X (2001) Nutrient characteristics in rhizosphere of pure and mixed plantations of Manchurian walnut and Dahurian larch. J For Res 12:18-20. https://doi.org/10.1007/BF02856793

Chen W, Koide RT, Adams TS, DeForest JL, Cheng L, Eissenstat DM (2016) Root morphology and mycorrhizal symbioses together shape nutrient foraging strategies of temperate trees. Proc Natl Acad Sci U S A 113:8741-8746. https://doi.org/10.1073/pnas.1601006113

Chen AQ, Gu M, Wang SS, Chen J, Xu G (2018) Transport properties and regulatory roles of nitrogen in arbuscular mycorrhizal symbiosis. Semin Cell Dev Biol 74:80-88. https://doi.org/10.1016/j. semcdb.2017.06.015

Chifflot V, Rivest D, Olivier A, Cogliastro A, Khasa D (2009) Molecular analysis of arbuscular mycorrhizal community structure and spores distribution in treebased intercropping and forest systems. Agric Ecosyst Environ 131:32-39. https://doi.org/10.1016/j.agee.2008. 11.010

Comas LH, Eissenstat DM (2009) Patterns in root trait variation among 25 co-existing North American forest species. New Phytol 182:919928. https://doi.org/10.1111/j.1469-8137.2009.02799.x

Comas LH, Callahan HS, Midford PE (2014) Patterns in root traits of woody species hosting arbuscular and ectomycorrhizas: implications for the evolution of belowground strategies. Ecol Evol 4: 2979-2990. https://doi.org/10.1002/ece3.1147

Cordell CE, Owen JH, Marx DH (1987) Mycorrhizae nursery management for improved seedling quality and field performance. In: Inter mountain Forest Nursery Association (ed) Meeting the Challenge of the Ninities Proceedings. Oklahoma General Technical Report RM 151, Oklahoma City, pp 105-115. http://rngr.net/publications/ proceedings/1987/cordell.pdf. Online document. Accessed 18 October 2019

Dana MN, Lerner BR (1990) Black walnut toxicity. Purdue University Extension, West Laffayette http://www.hort.purdue.edu/ext/HO193.pdf. Online document. Accessed 18 October 2019

Davies FT Jr (2008) How mycorrhizal fungi can benefit nursery propagation and production systems? Combined Proceedings International Plant Propagators' Society 58:539-548. http://aggiehorticulture.tamu.edu/Faculty/davies/research/abstracts/pdfs/200050-ipps.pdf. Online document. Accessed 18 October 2019

Delaviz H, Mohammadi J, Ghalamfarsa G, Mohammadi B, Farhadi N (2017) A review study on phytochemistry and pharmacology applications of Juglans regia plant. Pharmacogn Rev 11:145-152. https://doi.org/10.4103/phrev.phrev 1017

Dixon R (1988) Seed source and vesicular-arbuscular mycorrhizal symbiont affects growth of Juglans nigra seedlings. New For 2:203211. https://doi.org/10.1007/BF00029989

Dolcet-Sanjuan RE, Claveria E, Camprubi A et al (1996) Micropropagation of walnut trees (Juglans regia L.) and response to arbuscular mycorrhizal inoculation. Agronomie 16:639-645. https://doi.org/10.1051/agro:19961008

Dupraz C, Simorte V, Dauzat M et al (1999) Growth and nitrogen status of young walnuts as affected by intercropped legumes in a
Mediterranean climat. Agrofor Syst 43:71-80. https://doi.org/10. 1023/A:1026499103899

Duroux L, Delmotte FM, Lancelin JM et al (1998) Insight into naphthoquinone metabolism: beta-glucosidase-catalysed hydrolysis of hydrojuglone beta-D-glucopyranoside. Biochem J 333(Pt 2): 275-283. https://doi.org/10.1042/bj3330275

Eissenstat DM, Kucharski JM, Zadworny M, Adams TS, Koide RT (2015) Linking root traits to nutrient foraging in arbuscular mycorrhizal trees in a temperate forest. New Phytol 208:114-124. https:// doi.org/10.1111/nph.13451

Fajardo L, Cáceres A, Arrindell P (2014) Arbuscular mycorrhizae, a tool to enhance the recovery and re-introduction of Juglans venezuelensis Manning, an endemic tree on the brink of extinction. Symbiosis 64:63-71. https://doi.org/10.1007/s13199-014-0304-0

Feddermann N, Finlay R, Boller T, Elfstrand M (2010) Functional diversity in arbuscular mycorrhizal-the role of gene expression, phosphorus nutrition and symbiotic efficiency. Fungal Ecol 3:1-8. https:// doi.org/10.1016/j.funeco.2009.07.003

Fellbaum CR, Mensah JA, Cloos AJ, Strahan GE, Pfeffer PE, Kiers ET, Bücking H (2014) Fungal nutrient allocation in common mycorrhizal networks is regulated by the carbon source strength of individual host plants. New Phytol 203:646-656. https://doi.org/10.1111/nph. 12827

Ferlian O, Cesarz S, Craven D, Hines J, Barry KE, Bruelheide H, Buscot F, Haider S, Heklau H, Herrmann S, Kühn P, Pruschitzki U, Schädler M, Wagg C, Weigelt A, Wubet T, Eisenhauer N (2018) Mycorrhiza in tree diversity-ecosystem function relationships: conceptual framework and experimental implementation. Ecosphere 9: e02226. https://doi.org/10.1002/ecs2.2226

Fitter AH, Graves JD, Watkins NK, Robinson D, Scrimgeour C (1998) Carbon transfer between plants and its control in networks of arbuscular mycorrhizas. Funct Ecol 12:406-412. https://doi.org/10. 1046/j.1365-2435.1998.00206.x

Fortuna P, Citernesi S, Morini S, Giovannetti M, Loreti F (1992) Infectivity and effectiveness of different species of arbuscular mycorrhizal fungi in micropropagated plants of $\mathrm{Mr} \mathrm{S} 2 / 5$ plum rootstock. Agronomie 12:825-830. https://doi.org/10.1051/agro:19921015

Friese CF, Allen MF (1991) The spread of VA mycorrhizal fungal hyphae in the soil - inoculum types and external hyphal architecture. Mycologia 83:409-418. https://doi.org/10.2307/3760351

Garcia K, Zimmermann SD (2014) The role of mycorrhizal associations in plant potassium nutrition. Front Plant Sci 17:337. https://doi.org/ $10.3389 /$ fpls.2014.00337

Garrity D (2012) Agroforestry and the future of global land use. In: Nair $\mathrm{P}$, Garrity D (eds) Agroforestry - the future of global land use. Advances in Agroforestry, vol 9. Springer, Dordrecht. https://doi. org/10.1007/978-94-007-4676-3 6

Gauthier MM, Jacobs DF (2011) Walnut (Juglans spp.) ecophysiology in response to environmental stresses and potential acclimation to climate change. Ann For Sci 68:1277-1290. https://doi.org/10.1007/ s13595-011-0135-6

Gavito ME, Jakobsen I, Mikkelsen TN, Mora F (2019) Direct evidence for modulation of photosynthesis by an arbuscular mycorrhizainduced carbon sink strength. New Phytol 223:896-907. https:// doi.org/10.1111/nph.15806

Gerdemann JW (1975) Vesicular-arbuscular mycorrhizae. In: Torrey JG, Clarkson DT (eds) The development and function of roots. Academic, London, pp 575-591

Gerloff GC, Moore DG, Curtis JT (1964) The mineral content of native plants of Wisconsin. Wisconsin. Experimental Station. Res Re 14: $1-27$

Germain E (1992) Le noyer. In: Gallais A, Bannerot H (eds) Amélioration des espèces végétales. Objectifs et critères. Inra, Paris, pp 620-632

Gleeson SK (1982) Heterodichogamy in walnuts: inheritance and stable ratios. Evolution 36:892-902. https://doi.org/10.2307/2408070 
Gordon AM, Williams PA (1991) Intercropping valuable hardwood tree species and agricultural crops in southern Ontario. For Chron 67: 200-220. https://doi.org/10.5558/tfc67200-3

Gorzelak MA, Asay AK, Pickles BJ et al (2015) Inter-plant communication through mycorrhizal networks mediates complex adaptive behaviour in plant communities. AoB Plants 7:plv050. https://doi.org/ 10.1093/aobpla/plv050

Graham JH, Leonard RT, Menge JA (1981) Membrane-mediated decrease in root exudation responsible for phosphorus inhibition of vesicular-arbuscular mycorrhiza formation. Plant Physiol 68:548552. https://doi.org/10.1104/pp.68.3.548

Grossnickle SC (2005) The importance of root growth in overcoming planting stress. New For 30:273-294. https://doi.org/10.1007/ s11056-004-8303-2

Grossnickle SC, Folk RS (1993) Stock quality assessment: forecasting survival or performance on a reforestation site. Tree Planters Notes 44:113-121

Grossnickle SC, MacDonald JE (2018) Why seedlings grow: influence of plant attributes. New For 49:1-34. https://doi.org/10.1007/s11056017-9606-4

Grossnickle SC, MacDonald JE, Joanne E (2018) Seedling quality: history, application, and plant attributes. Forest 9:283. https://doi.org/ 10.3390/ 9050283

Guo D, Xia M, Wei X, Chang W, Liu Y, Wang Z (2008) Anatomical traits associated with absorption and mycorrhizal colonization are linked to root branch order in twenty-three Chinese temperate tree species. New Phytol 180:673-683. https://doi.org/10.1111/j.14698137.2008.02573.x

Gutjahr C, Parniske M (2013) Cell and developmental biology of arbuscular mycorrhiza symbiosis. Annu Rev Cell Dev Biol 29: 593-617. https://doi.org/10.1146/annurev-cellbio-101512-122413

Haase DL (2008) Understanding forest seedling quality: measurements and interpretation. Tree Planters Notes 52:24-30. http://pdfs. semanticscholar.org/43f1/8ca466d04d1e7de9363c95fd86d413a3c44c. pdf. Online document. Accessed 18 October 2019

Haase DL, Rose RW (1993) Soil moisture stress induces transplant shock in stored and unstored 2+0 Douglas-fir seedlings of varying root volumes. For Sci 39:275-294. https://doi.org/10.1093/ forestscience/39.2.275

Hackett W, Leslie C, Grant J, Lampinen B, McGranahan G, Anderson K, Beede B, Buchner R, Caprile J, DeBuse C, Hasey J, Manterola N, Robinson R, Kluepfel D, Browne G, and Mike McKenry M (2010) Clonal propagation of walnut rootstock genotypes for genetic improvement, walnut research reports. California walnut board, pp 65$83 \mathrm{http} / / /$ walnutresearch.ucdavis.edu/2010/2010_65.pdf. Online document. Accessed 18 October 2019

Harrison MJ, Dewbre GR, Liu J (2002) A phosphate transporter from Medicago truncatula involved in the acquisition of phosphate released by arbuscular mycorrhizal fungi. Plant Cell 14:2413-2429. https://doi.org/10.1105/tpc.004861

Hauggaard-Nielsen H, Jensen ES (2005) Facilitative root interactions in intercrops. Plant Soil 274:237-250. https://doi.org/10.1007/s11104004-1305-1

He XH, Critchley C, Bledsoe C (2003) Nitrogen transfer within and between plants through common mycorrhizal networks (CMNs). Crit Rev Plant Sci 22:531-567. https://doi.org/10.1080/713608315

van der Heijden MG, Horton TR (2009) Socialism in soil? The importance of mycorrhizal fungal networks for facilitation in natural ecosystems. J Ecol 97:1139-1150. https://doi.org/10.1111/j.13652745.2009.01570.x

van der Heijden MG, Martin FM et al (2015) Mycorrhizal ecology and evolution: the past, the present, and the future. New Phytol 205: 1406-1423. https://doi.org/10.1111/nph.13288

Heinemeyer A, Ineson P, Ostle N, Fitter AH (2006) Respiration of the external mycelium in the arbuscular mycorrhizal symbiosis shows strong dependence on recent photosynthates and acclimation to temperature. New Phytol 171:159-170. https://doi.org/10.1111/j. 1469-8137.2006.01730.x

Hejl AAM, Einhellig FA, Rasmussen JA (1993) Effects of juglone on growth, photosynthesis, and respiration. J Chem Ecol 19:559-568. https://doi.org/10.1007/BF00994325

Herrera-Peraza RA, Hamel C, Fernández F, Ferrer RL, Furrazola E (2011) Soil-strain compatibility: the key to effective use of arbuscular mycorrhizal inoculants? Mycorrhiza 21:183-193. https://doi.org/10.1007/s00572-010-0322-6

Hetrick BA, Leslie JF, Wilson GT et al (1988) Physical and topological assessment of effects of a vesicular-arbuscular mycorrhizal fungus on root architecture of big bluestem. New Phytol 110:85-96. https:// doi.org/10.1111/j.1469-8137.1988.tb00240.x

Hodge A (2004) The plastic plant: root responses to heterogeneous supplies of nutrients. New Phytol 162:9-24. https://doi.org/10.1111/j. 1469-8137.2004.01015.x

Hodge A, Fitter AH (2010) Substantial nitrogen acquisition by arbuscular mycorrhizal fungi from organic material has implications for $\mathrm{N} \mathrm{cy-}$ cling. Proc Natl Acad Sci U S A 107:13754-13759. https://doi.org/ 10.1073/pnas.1005874107

Huasen X, Huaxing B, Xi W et al. (2014) Root distribution variation of crops under walnut-based intercropping systems in the Loess Plateau of China. Pak J Agric Sci 51:773-778. http://www.pakjas. com.pk/papers/2340.pdf. Online document. Accessed 18 October 2019

Inderjit S (2005) Soil microorganisms: an important determinant of allelopathic activity. Plant Soil 274:227-236. https://doi.org/10.1007/ s11104-004-0159-x

Ingleby K, Wilson J, Munro RC, Cavers S (2007) Mycorrhizas in agroforestry: spread and sharing of arbuscular mycorrhizal fungi between trees and crops: complementary use of molecular and microscopic approaches. Plant Soil 294:125-136. https://doi.org/10.1007/ s11104-007-9239-z

Jacobs DF, Seifert JR (2004) Facilitating nutrient acquisition of black walnut and other hardwoods at plantation establishment. In: Michler CH, Pijut PM, Van Sambeek JW, Coggeshall MV, Seifert J, Woeste K, Overton R, Ponder F Jr (eds) Black walnut in a new century. Proceedings of the 6th Walnut Council Research Symposium. General Technical Report NC-243. Department of Agriculture, Forest Service, North Central Research Station, pp 66-St Paul, 70. http://www.nrs.fs.fed.us/pubs/gtr/gtr nc243/gtr nc243 066.pdf. Online document. Accessed 18 October 2019

Jacobs DF, Salifu KF, Seifert JR (2005a) Relative contribution of initial root and shoot morphology in predicting field performance of hardwood seedlings. New For 30:235-251. https://doi.org/10.1007/ s11056-005-5419-y

Jacobs DF, Salifu KF, Seifert JR (2005b) Growth and nutritional response of hardwood seedlings to controlled-release fertilization at outplanting. For Ecol Manag 214:28-39. https://doi.org/10.1016/j. foreco.2005.03.053

Jaiswal BS, Tailang M (2017) Juglans regia: a review of its traditional uses phytochemistry and pharmacology. Indo Am J Pharm Res 7(09). https://doi.org/10.5281/zenodo. 1036380

Janos DP (2007) Plant responsiveness to mycorrhizas differs from dependence upon mycorrhizas. Mycorrhiza 17:75-91. https://doi.org/10. 1007/s00572-006-0094-1

Jaynes RA (1979) Nut tree culture in North America. Northern Nut Growers Association, Hamden

Jones JE, Garrett HE, Haines J, Loewenstein EF (1995) Genetic selection and fertilization provide increased nut production under walnutagroforestry management. Agrofor Syst 29:265-273. https://doi. org/10.1007/BF00704873

Jose S (2009) Agroforestry for ecosystem services and environmental benefits: an overview. Agrofor Syst 76:1-10. https://doi.org/10. 1007/s10457-009-9229-7 
Jose S, Gillespie AR (1998) Allelopathy in black walnut (Juglans nigra L.) alley cropping. I. Spatio-temporal variation in soil juglone in a black walnut-corn (Zea mays L.) alley cropping system in the Midwestern USA. Plant Soil 203:191-197. https://doi.org/10. 1023/A:1004301309997

Jose S, Williams R, Zamora D (2006) Belowground ecological interactions in mixed-species forest plantations. For Ecol Manag 233:231239. https://doi.org/10.1016/j.foreco.2006.05.014

Kariman K, Barker SJ, Tibbett M (2018) Structural plasticity in rootfungal symbioses: diverse interactions lead to improved plant fitness. PeerJ 6:e6030. https://doi.org/10.7717/peerj.6030

Keymer A, Pimprikar P, Wewer V et al (2017) Lipid transfer from plants to arbuscular mycorrhiza fungi. eLife 6:e29107. https://doi.org/10. 7554/eLife. 29107

von Kiparski GR, Lee LS, Gillespie AR (2007) Occurrence and fate of the phytotoxin juglone in alley soils under black walnut trees. J Environ Qual 36:709-717. https://doi.org/10.2134/jeq2006.0231

Koide RT, Fernandez C, Malcolm G (2014) Determining place and process: functional traits of ectomycorrhizal fungi that affect both community structure and ecosystem function. New Phytol 201:433-439. https://doi.org/10.1111/nph.12538

Kong D, Wang J, Wu H, Valverde-Barrantes OJ, Wang R, Zeng H, Kardol P, Zhang H, Feng Y (2019) Nonlinearity of root trait relationships and the root economics spectrum. Nat Commun 10:2203. https://doi.org/10.1038/s41467-019-10245-6

Konvalinková T, Jansa J (2016) Lights off for arbuscular mycorrhiza: on its symbiotic functioning under light deprivation.Front. Plant Sci 7: 782. https://doi.org/10.3389/fpls.2016.00782

Kopinga J, van den Burg J (1995) Using soil and foliar analysis to diagnose the nutritional status of urban trees. J Arboric 21:17-24

Kormanik PP (1985) Effects of phosphorus and vesicular-arbuscular mycorrhizae on growth and leaf retention of black walnut seedlings. Can J For Res 15:688-693. https://doi.org/10.1139/x85-112

Kormanik PP (1986) Lateral root morphology as an expression of sweetgum seedling quality. For Sci 32:595-604. https://doi.org/10. 1093/forestscience/32.3.595

Kormanik PP (1989) Importance of first-order lateral roots in the early development of forest tree seedlings. Dev Soil Sci 18:157-169. https://doi.org/10.1016/S0166-2481(08)70210-1

Kormanik PP, Schultzz RC, Bryan WC (1982) The influence of vesicular-arbuscular mycorrhizae on the growth and development of eight hardwood tree species. For Sci 28:531-539. https://doi. org/10.1093/forestscience/28.3.531

de Kroon H, Hendriks M, van Ruijven J, Ravenek J, Padilla FM, Jongejans E, Visser EJW, Mommer L (2012) Root responses to nutrients and soil biota: drivers of species coexistence and ecosystem productivity. J Ecol 100:6-15. https://doi.org/10.1111/j.13652745.2011.01906.x

Kumar A, Shukla A, Hashmi S et al (2007) Effects of trees on colonization of intercrops by vesicular arbuscular mycorrhizae in agroforestry systems. Indian J Agric Sci 77:291-298

Landis TD (1985) Mineral nutrition as an index of seedling quality. In: Duryea ML (ed) Evaluating seedling quality, principles, Procedures and Predictive Abilities of Major Test. Forest Research Laboratory, Oregon State University, pp. 29-48

Landis TD, Tinus RW, McDonald SE, Barnett JP (1989) Seedling nutrition and irrigation. The container tree nursery manual, vol 4. USDA Forest Service Agriculture Handbook 674, Washington

Leake JR, Johnson D, Donnelly D, Muckle G, Boddy L, Read D (2004) Networks of power and influence: the role of mycorrhizal mycelium in controlling plant communities and agroecosystem functioning. Can J Bot 82:1016-1045. https://doi.org/10.1139/b04-060

Lerat S, Gauci R, Catford J et al $(2002){ }^{14} \mathrm{C}$ transfer between the spring ephemeral Erythronium americanum and sugar maple saplings via arbuscular mycorrhizal fungi in natural stands. Oecologia 132:181187. https://doi.org/10.1007/s00442-002-0958-9
Li L, Mccormack M, Chen F et al (2019) Different responses of absorptive roots and arbuscular mycorrhizal fungi to fertilization provide diverse nutrient acquisition strategies in Chinese fir. For Ecol Manag 433:64-72. https://doi.org/10.1016/j.foreco.2018.10.055

Liese R, Alings K, Meier IC (2017) Branching is a leading root trait of the plant economics spectrum in temperate trees. Front Plant Sci 8:315. https://doi.org/10.3389/fpls.2017.00315

Liu B, Li H, Zhu B, Koide RT, Eissenstat DM, Guo D (2015) Complementarity in nutrient foraging strategies of absorptive fine roots and arbuscular mycorrhizal fungi across 14 coexisting subtropical tree species. New Phytol 208:125-136. https://doi.org/10.1111/ nph.13434

Liu W, Zhang Y, Jiang S, Murray PJ et al (2019) Spatiotemporal differences in the arbuscular mycorrhizal fungi communities in soil and roots in response to long-term organic compost inputs in an intensive agricultural cropping system on the North China Plain. J Soils Sediments 19:2520-2533. https://doi.org/10.1007/s11368-01902244-3

Lopez JM (2004) Walnut tissue culture: research and field applications. In: Michler CH, Pijut PM, Van Sambeek JW, Coggeshall MV, Seifert J, Woeste K, Overton R, Ponder F Jr (eds) Black walnut in a new century, Proceedings of the 6th Walnut Council Research Symposium, General Technical Report NC-243. Department of Agriculture, Forest Service, North Central Research Station, St Paul, pp 146-152 http://www.nrs.fs.fed.us/pubs/gtr/gtr_nc243/gtr nc243_146.pdf. Online document. Accessed 18 October 2019

Malézieux E, Crozat Y, Dupraz C, Laurans M, Makowski D, OzierLafontaine H, Rapidel B, Tourdonnet S, Valantin-Morison M (2009) Mixing plant species in cropping systems: concepts, tools and models. A review. Agron Sustain Dev 29:43-62. https://doi. org/10.1051/agro:2007057

Manning WE (1978) The classification within the Juglandaceae. Ann Missouri Bot Gard 65:1058-1087. https://doi.org/10.2307/2398782

Martinez ML, Labuckas DO, Lamarque AL et al (2010) Walnut (Juglans regia L.): genetic resources, chemistry, by-products. J Sci Food Agric 90:1959-1967. https://doi.org/10.1002/jsfa.4059

Martins MA, Cruz AF (1998) The role of the external mycelial network of arbuslar mycorrhizal fungi. III. A study of nitrogen transfer between plants interconnected by a common mycelium. Rev Microbiol 29:289-294. https://doi.org/10.1590/S000137141998000400011

Mary F, Dupraz C, Delannoy E et al (1998) Incorporating agroforestry practices in the management of walnut plantations in Dauphiné, France: an analysis of farmers' motivations. Agrofor Syst 43:243256. https://doi.org/10.1023/A:1026425307959

Massey AB (1925) Antagonism of the walnuts (Juplans nigra L., and Juglans olnerea L.) in certain plant association. Phytopathol 15 : 775-785

McCormack ML, Dickie IA, Eissenstat D et al (2015) Redefining fine roots improves understanding of below-ground contributions to terrestrial biosphere processes. New Phytol 207:505-518. https://doi. org/10.1111/nph.13363

McHargue JS, Roy NR (1932) Mineral and nitrogen content of the leaves of some forest trees at different times in the growing season. Bot Gaz 94:381-395. https://doi.org/10.1086/334303

Melichar MW, Garrett HE, Cox GS (1986) Mycorrhizae benefit growth and development of eastern black walnut seedlings. North J Appl For 3:151-153. https://doi.org/10.1093/njaf/3.4.151

Mills HA, Jones JB (1996) Plant analysid handbook II: a practical sampling, preparation, analysis, and interpretation guide. MicroMacro Publishing Inc, Athens

Mohni CPF, Pelleri F, Hemery GE (2009) The modern silviculture of Juglans regia L.: a literature review. Die Bodenkultur 60:19-32. http://pdfs. semanticscholar.org/4f0a/a056625285740786879ac7e02e3bdf9a379c. pdf. Online document. Accessed 18 October 2019 
Montesinos-Navarro A, Verdú M, Querejeta JI, Sortibrán L, ValienteBanuet A (2016) Soil fungi promote nitrogen transfer among plants involved in long-lasting facilitative interactions. Perspect Plant Ecol 18:45-51. https://doi.org/10.1016/j.ppees.2016.01.004

Moses A, Popoola O, Olawuyi OJ et al (2013) Harnessing the potentials of vesicular arbuscular mycorrhizal (VAM) fungi to plant growtha review. Int J Pure Appl Sci Technol 14:61-79

Mosquera-Losada MR, McAdam J, Romero-Franco R et al (2009) Definitions and components of agroforestry practices in Europe. In: Rigueiro-Rodríguez A, McAdam J, Mosquera-Losada MR (eds) Agroforestry in Europe, Advances in agroforestry, vol 6. Springer, Dordrecht, pp 3-19. https://doi.org/10.1007/978-1-40208272-6 1

Nair PKR (1993) An introduction to agroforestry. Kluwer Academic Publishers, Dordrecht

Newman SM (2006) Agronomic and economic aspects of walnut agroforestry in the UK. In: Malvolti D, Avazato D (eds) Proceedings Fifth International Walnut Symposium, Acta Hortic, vol 705, pp 6567

van Noordwijk M, Lawson G, Sournard A et al (1996) Root distribution of trees and crops: competition and/or complementarity. In: Ong CK, Huxley PA (eds) Tree-crop interactions: a physiological approach. CAB International, Wallingford, Oxford, pp 319-364

Olsen J (2006) Growing walnuts in Oregon. Oregon State University Extension Publication EM 8907 http://ir.library. oregonstate.edu/ xmlui/bitstream/handle/1957/20433/ em8907.pdf. Online document. Accessed 18 October 2019

Pagano M, Cabello M (2011) Mycorrhizal interactions for reforestation: constraints to dryland agroforest in Brazil. ISRN Ecol 2011:1-13. https://doi.org/10.5402/2011/890850

Pagès L (2002) Modelling root system architecture. In: Waisel Y, Eshel A, Kafkafi U (eds) Plant roots: the hidden half. Marcel Dekker, New York, pp 359-382

Payghamzadeh K, Kazemitabar SK (2011) In vitro propagation of walnut - a review. Afr J Biotechnol 10:290-311. https://doi.org/ 10.5897/AJB10.324

Peixe AP, Alpendre J, Barroso R et al (2015) New strategies for in vitro rooting and plantlet acclimatization of the 'Paradox' (Juglans regia $\times$ Juglans hindsii) rootstock. Acta Hortic 1083:287-293. https://doi. org/10.17660/ActaHortic.2015.1083.36

Perry DA, Molina R, Amaranthus MP (1987) Mycorrhizae, mycorrhizospheres, and reforestation: current knowledge and research needs. Can J For Res 17:929-940. https://doi.org/10.1139/x87-145

Phares RF, Finn RF (1971) Using foliage analysis to help diagnosis nutrient deficiencies in black walnut. North Nut Grow Assoc Ann Rep 62:98-104

PIRAT (2012) Programme Intégré de recherches en Agroforesterie à Restinclières. http://recherche.agroof.net/fichesR\&D/docs/rapport pirat 2012.pdf. Online document. Accessed 18 October 2019

Plenchette C, Fortin JA, Furlan V (1983) Growth responses of several plant species to mycorrhizae in a soil of moderate P-fertility. I. Mycorrhizal dependency under field conditions. Plant Soil 70: 199-209. https://doi.org/10.1007/BF02374780

Plenchette C, Clermont-Dauphin C, Meynard JM, Fortin JA (2005) Managing arbuscular mycorrhizal fungi in cropping systems. Can J Plant Sci 85:31-40. https://doi.org/10.4141/P03-159

Ponder F Jr (1998) Fertilizer combinations benefit diameter growth of plantation black walnut. J Plant Nutr 21:1329-1337. https://doi.org/ $10.1080 / 01904169809365486$

Ponder F Jr (2004) Soils and nutrition management for black walnuts. In: Michler CH, Pijut PM, van Sambeek JW, Coggeshall MV, Seifert J, Woeste K, Overton R, Ponder F Jr (eds) Proceedings of the 6th Walnut Council Research Symposium, Geneneral Techenical.
Report NC-243. Department of Agriculture, Forest Service, North Central Research Station, Saint Paul, pp 71-76 http://www.nrs.fs. fed.us/pubs/gtr/gtr_nc243/gtr_nc243_071.pdf. Online document. Accessed 18 October 2019

Pregitzer KS (2002) The fine roots of trees - a new perspective. New Phytol 156:267-270. https://doi.org/10.1046/j.1469-8137.2002. 00413 1.x

Pregitzer KS, DeForest JL, Burton AJ et al (2002) Fine root architecture of nine North American trees. Ecol Monogr 72:293-309. https://doi. org/10.1890/0012-9615(2002)072[0293:fraonn]2.0.co;2

Rai MK (2001) Current advances in mycorrhization in micropropagation. In Vitro Cell Dev Biol Plant 37:158-167. https://doi.org/10.1007/ s11627-001-0028-8

Raven JA, Edwards D (2001) Roots: evolutionary origins and biogeochemical significance. J Exp Bot 52:381-401. https://doi.org/10. 1093/jexbot/52.suppl_1.381

Rehnus M, Mamadzhanov D, Venglovsky BI, Sorg JP (2013) The importance of agroforestry hay and walnut production in the walnutfruit forests of southern Kyrgyzstan. Agrofor Syst 87:1-12. https:// doi.org/10.1007/s10457-012-9516-6

Reid W, Coggeshall MV, Garrett HE, van Sambeek JW (2009) Growing black walnut for nut production. University of Missouri Center for Agroforestry"Agroforestry in Action" Publication AF1011 http:// www.centerforagroforestry.org/pubs/walnutNuts.pdf. Online document. Accessed 18 October 2019

Reynolds PE, Simpson JA, Thevathasan NV, Gordon AM (2007) Effects of tree competition on corn and soybean photosynthesis, growth, and yield in a temperate tree-based agroforestry intercropping system in southern Ontario, Canada. Ecol Eng 29:362-371

Rich MK, Nouri E, Courty PE, Reinhardt D (2017) Diet of Arbuscular Mycorrhizal Fungi: bread and butter? Trends Plant Sci 22:652-660. https://doi.org/10.1016/j.tplants.2017.05.008

Rietveld WJ (1981) Significance of allelopathy in black walnut cultural systems. North Nut Grow Assoc Ann Rep 72:117-134

Rietveld WJ (1983) Allelopathic effects of juglone on germination and growth of several herbaceous and woody species. J Chem Ecol 9: 295-308. https://doi.org/10.1007/BF00988047

Rietveld WJ (1989) Transplanting stress in bareroot conifer seedlings: its development and progression to establishment. North J Appl For 6: 99-107. https://doi.org/10.1093/njaf/6.3.99

Rohr R, Iliev I, Scaltsoyinnes A et al (2003) Acclimatization of micropropagated forest trees. Acta Hortic 616:59-69. https://doi. org/10.17660/ActaHortic.2003.616.3

Roth R, Paszkowski U (2017) Plant carbon nourishment of arbuscular mycorrhizal fungi. Curr Opin Plant Biol 39:50-56. https://doi.org/ 10.1016/j.pbi.2017.05.008

Rowe EC, Hairiah K, Giller KE, van Noordwijk M, Cadisch G (1999) Testing the safety-net role of hedgerow tree roots by ${ }^{15} \mathrm{~N}$ placement at different soil depth. Agrofor Syst 43:81-93. https://doi.org/10. 1023/A:1022123020738

Salahuddin RB, Razaq M, Lixue Y et al (2018) Root order-based traits of Manchurian walnut \& larch and their plasticity under interspecific competition. Sci Rep 8:9815. https://doi.org/10.1038/s41598-018-27832-0

Salifu KF, Jacobs DF, Pardillo G et al (2006) Response of grafted Juglans nigra to increasing nutrient availability: growth, nutrition, and nutrient retention in root plugs. Hortic Sci 41:1477-1480. https://doi. org/10.21273/HORTSCI.41.6.1477

van Sambeek JW (2017) Cover crops to improve soil health and pollinator habitat in nut orchards: part II. Missouri nut grow. Assoc Newslett 17:6-12. http://www.fs.fed.us/nrs/pubs/jrnl/2017/nrs 2017 vansambeek 003.pdf. Online document. Accessed $1 \overline{8}$ October 2019 
van Sambeek JW, Garrett HE (2004) Ground cover management in walnut and other hardwood plantings. In: Michler $\mathrm{CH}$, Pijut PM, van Sambeek JW, Coggeshall MV, Seifert J, Woeste K, Overton R, Ponder F Jr (eds) Proceedings of the 6th Walnut Council Research Symposium, Geneneral Techenical. Report NC-243. Department of Agriculture, Forest Service, North Central Research Station, Saint Paul, pp 100-105 http://www.nrs.fs.fed.us/pubs/gtr/gtr_nc243/gtr nc243 085.pdf. Online document. Accessed 18 October 2019

Schubert A, Lubraco G (2000) Mycorrhizal inoculation enhances growth and nutrient uptake of micropropagated apple rootstocks during weaning in commercial substrates of high nutrient availability. Appl Soil Ecol 15:113-118. https://doi.org/10.1016/S09291393(00)00086-X

Schultz RC, Kormanik PP (1982) Vesicular-arbuscular mycorrhiza and soil fertility influence mineral concentrations in seedlings of eight hardwood species. Can J For Res 12:829-834. https://doi.org/10. $1139 / \mathrm{x} 82-124$

Schultz RC, Thompson JR (1990) Nursery practices that improve hardwood seedling root morphology. Tree Planters Notes 41:21-32 http://lib.dr.iastate.edu/for_pubs/13. Online document. Accessed 18 October 2019

Schultz RC, Kormanik PP, Bryan WC (1981) Effects of fertilization and vesicular-arbuscular mycorrhizal inoculation on growth of hardwood seedlings. Soil Sci Soc Am J 45:961-965. https://doi.org/10. 2136/sssaj1981.03615995004500050029x

Serr EF (1960) Respone of Persian walnut to superphosphate. Proc Am Soc Hortic Sci 77:301-307

Shah UN, Mir JI, Ahmed N et al (2018) Bio-techniques for improvement of qualitative and quantitative traits in walnut (Juglans regia). Adv Hortic Sci 32:113-135. https://doi.org/10.13128/ahs-21330

Sharda JN, Koide RT (2008) Can hypodermal passage cell distribution limit root penetration by mycorrhizal fungi? New Phytol 180:696701. https://doi.org/10.1111/j.1469-8137.2008.02600.x

Sharma A, Singh S, Srivastava K et al (2003) Studies on success of walnut grafting as affected by time and environment. Ind $\mathrm{J}$ Ecol $18: 123-125$

Shukla A, Kumar A, Anuradha A et al (2009) Effects of shade on arbuscular mycorrhizal colonization and growth of crops and tree seedlings in Central India. Agrofor Syst 76:95-109. https://doi.org/ 10.1007/s10457-008-9182-x

Shukla A, Kumar A, Jha A, Dhyani SK, Vyas D (2012) Cumulative effects of tree based intercropping on arbuscular mycorrhizal fungi. Biol Fertil Soils 48:899-909. https://doi.org/10.1007/s00374-012-0682-5

Simard S, Durall DM (2004) Mycorrhizal networks: a review of their extent, function, and importance. Can J Bot 82:1140-1165. https:// doi.org/10.1139/b04-116

Simard SW, Perry DA, Jones MD, Myrold DD, Durall DM, Molina R (1997) Net transfer of carbon between tree species with shared ectomycorrhizal fungi. Nature 388:579e582-579e582. https://doi. org $/ 10.1038 / 41557$

Simorte V, Bertoni G, Dupraz C, Masson P (2001) Assessment of nitrogen nutrition of walnut trees using foliar analysis and chlorophyll measurements. J Plant Nutr 24:1645-1660. https://doi.org/10.1081/ PLN-100106027

Siqueira JO, Saggin-Júnior OJ (2001) Dependency on arbuscular mycorrhizal fungi and responsiveness of some Brazilian native woody species. Mycorrhiza 11:245-255. https://doi.org/10.1007/ s005720100129

Smith MW (2003) Mineral nutrition. In: Fulbright DW (ed) Nut tree in North America, vol 1. McNaughton and Gunn, Inc. and North Nut Grow Assoc, Saline, pp 317-346

Smith SE, Read DJ (1997) Mycorrhizal symbiosis, 2nd edn. Academic Press, London
Smith SE, Read DJ (2008) Mycorrhizal symbiosis, 3rd edn. Academic Press and Elsevier, London

Spatafora JW, Chang Y, Benny GL et al (2016) A phylum-level phylogenetic classification of zygomycete fungi based on genome-scale data. Mycologia 108:1028-1046. https://doi.org/10.3852/16-042

Strugstad M, Despotovski S (2012) A summary of extraction, synthesis, properties, and potential uses of juglone: a literature review. J Ecosyst Manag 13:1-16. http://jem-online.org/index.php/jem/ article/view/119/473. Online document. Accessed 18 October 2019

Sun Y, Yang L, Wang Z et al (2013) Temporal variations in soil juglone and soil microbial community structure under Manchurian walnut (Juglans mandshurica Maxim.) plantations. Allelopath J 31:169180

Szabó K, Boll S, Eros-Honti Z (2014) Applying artificial mycorrhizae in planting urban trees. Appl Ecol Environ Res 12:835-853. https:// doi.org/10.15666/aeer/1204_835853

Teste FP, Simard SW, Durall DM, Guy RD, Jones MD, Schoonmaker AL (2009) Access to mycorrhizal networks and tree roots: importance for seedling survival and resource transfer. Ecology 90: 2808e2822-2808e2822. https://doi.org/10.1890/08-1884.1

van Tuinen D, Tranchard E, Hirissou F et al (2020) Carbon partitioning in a walnut-maize agroforestry system through arbuscular mycorrhizal fungi. Rhizosphere 100230:100230. https://doi.org/10.1016/j. rhisph.2020.100230

Unger S, Friede M, Volkmar K, Hundacker J, Beyschlag W (2017) Relationship between mycorrhizal responsiveness and root traits in European sand dune species. Rhizosphere 3:160-169. https://doi. org/10.1016/j.rhisph.2017.04.008

Verheye WH (2006) Management of agricultural land: chemical and fertility aspects. In: Verheye WH (ed) Land use, land cover and soil sciences. UNESCO-EOLSS Publishers, -Oxford. http://www.eolss. net/Sample-Chapters/C19/E1-05-04-02.pdf. Online document. Accessed 18 October 2019

Verma MK (2014) Walnut production technology. In: Singh SK, Munshi $\mathrm{AD}$, Prasad KV, Sureja (eds) Training manual on teaching of postgraduate courses in horticulture (Fruit Science). Post Graduate School, Indian Agricultural Research Institute, New Delhi

Walder F, Niemann H, Natarajan M, Lehmann MF, Boller T, Wiemken A (2012) Mycorrhizal networks: common goods of plants shared under unequal terms of trade. Plant Physiol 159:789-797. https://doi. org/10.1104/pp.112.195727

Waldron A, Garrity D, Malhi Y, Girardin C, Miller DC, Seddon N (2017) Agroforestry can enhance food security while meeting other sustainable development goals. Trop Conserv Sci 10:194008291772066. https://doi.org/10.1177/1940082917720667

Wang B, Qiu YL (2006) Phylogenetic distribution and evolution of mycorrhizas in land plants. Mycorrhiza 16:299-363. https://doi.org/10. 1007/s00572-005-0033-6

Wang W, Shi J, Xie Q, Jiang Y, Yu N, Wang E (2017) Nutrient exchange and regulation in arbuscular mycorrhizal symbiosis. Mol Plant 10: 1147-1158. https://doi.org/10.1016/j.molp.2017.07.012

Wells CE, Eissenstat DM (2001) Marked differences in survivorship among apple roots of different diameters. Ecology 82:882-889. https://doi.org/10.1890/0012-9658(2001)082[0882:MDISAA]2.0. $\mathrm{CO} ; 2$

Willis RJ (2000) Juglans spp., juglone and allelopathy. Allelopath J 7:155

Wilson BC, Jacobs DF (2006) Quality assessment of temperate zone deciduous hardwood seedlings. New For 31:417-433. https://doi. org/10.1007/s11056-005-0878-8

Wipf D, Krajinski F, van Tuinen D et al (2019) Trading on the arbuscular mycorrhiza market: from arbuscule to common mycorrhizal 
networks. New Phytol 223:1127-1142. https://doi.org/10.1111/nph. 15775

Wolz KJ, DeLucia EH (2019) Black walnut alley cropping is economically competitive with row crops in the Midwest USA. Ecol Appl 29:e01829. https://doi.org/10.1002/eap.1829

Xia M, Guo D, Pregitzer KS (2010) Ephemeral root modules in Fraxinus mandshurica. New Phytol 188:1065-1074. https://doi.org/10.1111/ j.1469-8137.2010.03423.x

Yang L, Wang P, Kong C (2010) Effect of larch (Larix gmelini Rupr.) root exudates on Manchurian walnut (Juglans mandshurica Maxim.) growth and soil juglone in a mixed-species plantation. Plant Soil 329:249-258. https://doi.org/10.1007/s11104-009-0149-0

Zadworny M, Eissenstat DM (2011) Contrasting the morphology, anatomy and fungal colonization of new pioneer and fibrous roots. New Phytol 190:213-221. https://doi.org/10.1111/j.1469-8137.2010. 03598.x

Publisher's note Springer Nature remains neutral with regard to jurisdictional claims in published maps and institutional affiliations. 